\title{
Review \\ Fibers by Electrospinning and Their Emerging Applications in Bone Tissue Engineering
}

\author{
Chuqun Yang ${ }^{1,+}$, Qi Shao ${ }^{1,+}$, Yulai Han ${ }^{1, *}$, Qingxia Liu ${ }^{1}$, Liang He ${ }^{2} \mathbb{D}$, Qian Sun ${ }^{3, *}$ and Shuangchen Ruan ${ }^{1, *}$ \\ 1 College of New Materials and New Energies, Shenzhen Technology University, Shenzhen 518118, China; \\ 2070413007@stumail.sztu.edu.cn (C.Y.); shaoqi@sztu.edu.cn (Q.S.); liuqingxia@sztu.edu.cn (Q.L.) \\ 2 School of Mechanical Engineering, Sichuan University, Chengdu 610065, China; hel20@scu.edu.cn \\ 3 College of Health Science and Environmental Engineering, Shenzhen Technology University, \\ Shenzhen 518118, China \\ * Correspondence: hanyulai@sztu.edu.cn (Y.H.); sunqian2@sztu.edu.cn (Q.S.); scruan@sztu.edu.cn (S.R.) \\ + Contribute equally.
}

check for

updates

Citation: Yang, C.; Shao, Q.; Han, Y.; Liu, Q.; He, L.; Sun, Q.; Ruan, S. Fibers by Electrospinning and Their Emerging Applications in Bone Tissue Engineering. Appl. Sci. 2021, 11, 9082. https://doi.org/10.3390/ app11199082

Academic Editors: Diana Ferreira,

Raul Fangueiro and

Seeram Ramakrishna

Received: 29 August 2021

Accepted: 23 September 2021

Published: 29 September 2021

Publisher's Note: MDPI stays neutral with regard to jurisdictional claims in published maps and institutional affiliations.

Copyright: (C) 2021 by the authors Licensee MDPI, Basel, Switzerland. This article is an open access article distributed under the terms and conditions of the Creative Commons Attribution (CC BY) license (https:// creativecommons.org/licenses/by/ $4.0 /)$.
Abstract: Bone tissue engineering (BTE) is an optimized approach for bone regeneration to overcome the disadvantages of lacking donors. Biocompatibility, biodegradability, simulation of extracellular matrix (ECM), and excellent mechanical properties are essential characteristics of BTE scaffold, sometimes including drug loading capacity. Electrospinning is a simple technique to prepare fibrous scaffolds because of its efficiency, adaptability, and flexible preparation of electrospinning solution. Recent studies about electrospinning in BTE are summarized in this review. First, we summarized various types of polymers used in electrospinning and methods of electrospinning in recent work. Then, we divided them into three parts according to their main role in BTE, (1) ECM simulation, (2) mechanical support, and (3) drug delivery system.

Keywords: fiber; scaffold; electrospinning; bone tissue engineering

\section{Introduction}

Bone defects, caused by tumors, trauma, and infections, have posed serious challenges for clinical treatment. Among traditional methods, autograft transplantation is regarded as the "gold standard" for repairing critical-sized bone defects without adverse immune response due to its significant osteoinductivity and osteoconductivity [1]. However, the use of autografts also suffers inevitable drawbacks, such as limited clinical availability, multiple operations, and morbidity at the donor site [2,3]. Moreover, allogeneic bone transplantation has caused disease transmission and immunoreaction, which are seriously concerned. Therefore, bone tissue engineering (BTE) has been introduced as an optimized method for bone regeneration to overcome the shortcomings of lacking donors. An ideal BTE scaffold should exhibit biocompatibility, biodegradability, and suitable mechanical strength, and imitate the extracellular matrix (ECM) to regulate cell behavior [4]. Fibrous scaffolds are considered to enhance cell adhesion due to high specific surface area. There are various techniques employed to fabricate fibrous scaffolds, such as self-assembly [5], phase separation [6], and electrospinning [7].

Electrospinning is a simple technique to prepare fibers with diameters ranging from nanoscale to micron by uniaxial stretching of the charged jet. This technique has attracted great attention because of its efficiency, adaptability, and flexible preparation of electrospinning solution. Owing to these remarkable features, electrospun fibers have been widely used in different fields [8]. Recently, different kinds of electrospinning processes were proposed and optimized to achieve favorable structures and properties, as shown in Table 1.

During the process of electrospinning, the morphologies and properties of electrospun fibers are directly affected by various parameters. These parameters significantly influence 
the spinnability, diameter, and orientation/alignment of fibers. Spinnability, defined as the ability of polymers to form stable fibers, mainly depends on solution parameters including surface tension, viscosity, and conductivity [8]. Surface tension is affected by solvent and concentration of polymer solution. The uniaxial stretch of a charged jet is hardly achieved with low surface tension. Viscosity, determined by the molecular weight of polymer and concentration of polymer solution, also affects spinnability due to polymer chain entanglement. In addition, temperature is a notable factor affecting viscosity. By adding salts, conductivity is increased to help optimize the formation of fibers. The diameter of fibers is affected by the molecular weight of polymer, concentration of polymer solution, instrumental parameters (voltage, flow rate, tip to collector distance), and humidity. The diameter of fibers can be controlled by adjusting the applied voltage and enhancing the stretching of polymer solution. Meanwhile, the flow rate of polymer solution should be optimized to match the applied voltage for uniform fibers. Moreover, different orientation or alignment of fibers can be achieved by selecting different types of collectors like drum, disk, plate, or other customized collectors.

In recent years, there have been many attempts combining electrospinning methods with BTE scaffolds. Electrospun fibers, exhibiting similar topological features with ECM, were employed to provide a suitable environment for the adhesion and growth of cells [9]. Furthermore, without any chemical cues, the fiber structure is able to promote osteogenic differentiation in vitro [10]. In order to satisfy the requirement of BTE scaffolds, various polymers have been applied for preparing electrospun fibers. Table 2 shows examples of natural and synthesized polymers used as matrices of electrospun fibrous scaffolds.

Table 1. Examples of electrospinning methods.

\begin{tabular}{|c|c|c|c|}
\hline & Method & Advantage & Ref. \\
\hline \multirow{4}{*}{ Fiber composition } & Coaxial electrospinning & $\begin{array}{l}\text { Beneficial for materials without ability to form fibers } \\
\text { as core; providing fibers abilities of sustained } \\
\text { delivery; enabling surface functionalization without } \\
\text { affecting the core material. }\end{array}$ & [11-22] \\
\hline & Fiber blending & $\begin{array}{l}\text { Fiber with the properties of two separate polymers; } \\
\text { enhancing both mechanical and bioactive properties. }\end{array}$ & [23] \\
\hline & Emulsion electrospinning & $\begin{array}{c}\text { Fabricating porous fibers to enhance mesh porosity; } \\
\text { retaining bioactivity and promoting sustained } \\
\text { release by encapsulating enzymes, growth factors, } \\
\text { and drugs. }\end{array}$ & [24-27] \\
\hline & Edge electrospinning & Enhancing collection efficiency by changing jet sites. & [28] \\
\hline \multirow{5}{*}{ Fiber orientation } & Rotating mandrel alignment & $\begin{array}{l}\text { With increasing rotational speed, the modulus and } \\
\text { tensile stress of fibers in the direction of alignment } \\
\text { increase. }\end{array}$ & {$[11,13,22,27,29-39]$} \\
\hline & Gap electrospinning & $\begin{array}{l}\text { Producing highly aligned fibers; fabricating complex } \\
\text { architecture by modulating electrode configuration. }\end{array}$ & [40] \\
\hline & Magnetic electrospinning & $\begin{array}{l}\text { Leading to a reduction in branching; maintaining } \\
\text { alignment over time. }\end{array}$ & [41] \\
\hline & Pattern spinneret & $\begin{array}{l}\text { Controlling deposition of electrospun fibers to } \\
\text { produce specific architecture for generating specific } \\
\text { cellular distributions and orientation. }\end{array}$ & [42] \\
\hline & Moving spinneret & $\begin{array}{c}\text { Enhancing flexibility through curly or wavy } \\
\text { architectures. }\end{array}$ & [43] \\
\hline \multirow{3}{*}{$\begin{array}{l}\text { Mesh architecture } \\
\text { and composition }\end{array}$} & Co-electrospinning & $\begin{array}{c}\text { Controlling the mechanical properties and cellular } \\
\text { behavior by altering the weight ratio of each } \\
\text { material. }\end{array}$ & [44-46] \\
\hline & Layer-by-layer hydrospinning & Fabricating scaffolds with polymeric fiber layers. & {$[47,48]$} \\
\hline & 3D electrospinning & Fabricating controlled specific 3D architecture. & [49-52] \\
\hline
\end{tabular}


Table 2. Examples of electrospun polymeric metrices used in BTE.

\begin{tabular}{|c|c|c|c|}
\hline Me & & Feature & Ref. \\
\hline \multirow{6}{*}{ Synthetic polymers } & PCL & $\begin{array}{l}\text { Biocompatible, bioresorbable and cost } \\
\text { efficient; but its hydrophobicity results } \\
\text { in lack of cell attachment. }\end{array}$ & {$[12,14-18,22,24,25,29,31,32,38,53-79]$} \\
\hline & PLA & $\begin{array}{c}\text { Excellent mechanical properties and } \\
\text { low degradation rate; inflammatory } \\
\text { reactions caused by its degradation } \\
\text { product. }\end{array}$ & {$[30,42,80-93]$} \\
\hline & PLGA & $\begin{array}{c}\text { Faster and adjustable degradation rate } \\
\text { compared to PLA. }\end{array}$ & {$[27,41,46,94-97]$} \\
\hline & PVA & $\begin{array}{c}\text { Can be processed with various degrees } \\
\text { of hydrolysis for drug delivery to } \\
\text { promote bone repair. }\end{array}$ & {$[52,98-101]$} \\
\hline & PVDF & $\begin{array}{l}\text { Inherent piezoelectricity that mimics } \\
\text { the ECM for bone regeneration; } \\
\text { delivering an electric stimulus without } \\
\text { the need for an external power source. }\end{array}$ & {$[102,103]$} \\
\hline & Polyaniline (PANI) & $\begin{array}{l}\text { Electrical conductivity promoting cell } \\
\text { adhesion, migration, and } \\
\text { differentiation; proper biocompatibility } \\
\text { and fair hydrophobicity. }\end{array}$ & [104] \\
\hline \multirow{7}{*}{ Natural polymers } & & Strong mechanical properties, & \\
\hline & Silk fibroin & biocompatibility, low degradation rate, & {$[19,44,47,105-107]$} \\
\hline & & immunogenic responses in vivo. & \\
\hline & & $\begin{array}{l}\text { A structurally similar derivative of } \\
\text { collagen; higher tensile moduli than }\end{array}$ & \\
\hline & Gelatin & electrospun collagen; excellent & {$[13,21,45,95,96,108-110]$} \\
\hline & & $\begin{array}{l}\text { biodegradability, non-antigenicity, and } \\
\text { cost efficiency. }\end{array}$ & \\
\hline & Collagen & $\begin{array}{l}\text { Native component of ECM, low } \\
\text { antigenicity; low inflammatory and } \\
\text { cytotoxic responses. }\end{array}$ & {$[20,39,111]$} \\
\hline
\end{tabular}

In this paper, different kinds of electrospinning methods and main polymers recently employed in electrospinning were summarized. Then, we reviewed the emerging application of electrospun nanofibers in BTE, focusing on three aspects including ECM simulation, mechanical support, and drug delivery system.

\section{ECM Simulation}

ECM simulation is a key part of BTE. ECM provides the tissue with growth factors and nutrients for controlling cell proliferation and differentiation under a special environment [112-114]. To meet the requirements of BTE, the fibrous scaffold prepared by electrospinning should not only provide structure and mechanical robustness for the tissue, but also mimic native ECM for bone tissue repair. Three methodologies are employed to achieve this goal, i.e., (1) selection of scaffold components, (2) improvement of spinning methods, and (3) processing after spinning.

In BTE, several natural and synthetic polymers (shown in Table 2) are electrospun because of their biocompatibility. Electrospinning can be defined as an electrohydrodynamic process: when the potential energy formed by the potential difference is higher than the surface tension of the polymer solution, a Taylor cone is formed from a spherical droplet under the applied voltage; then, the polymer solution will be mechanically stretched under the action of the electric field and form fibers with solvent evaporation $[115,116]$. The performance of the fibers mainly depends on the inherent properties of polymers. Piezoelectricity is one of the inherent properties of bone, attributed to the piezoelectric effect of the crystalline micelle of collagen [117]. The electrical signals produced by bone promotes 
bone growth and remodeling [118]. Poly (vinylidene fluoride) (PVDF), a kind of piezoelectric materials in BTE, has high hydrophobicity which is not conducive to cell adhesion and cell proliferation. Kitsara et al. [119] found that the piezoelectric electrospun nanofibers enhanced cell activation confirmed by intracellular calcium imaging. According to this discovery, they combined the advantages of both electrospinning and plasma treatment to develop a 3D tissue-like functional self-sustainable scaffold for BTE. Because of piezoelectricity, the scaffold released a piezoelectric potential. It stimulated the voltage-gated calcium channels (VGCC) in the cell membrane and caused cell activation (Figure 1) [120]. The results showed that a functional and stable hydrophilic scaffold could be fabricated by the combination of a highly $\beta$-phase electrospun PVDF with oxygen plasma treatment. Svetlana et al. [33] used electrospinning process to fabricate 3D hybrid scaffolds based on piezoelectric poly(3-hydroxybutyrate-co-3-hydroxyvalerate) (PHBV). It was discovered, compared with non-piezoelectric polycaprolactone (PCL) scaffolds, 3D hybrid scaffolds revealed more superior osteoinductive properties because of the improvement of degree of mineralization and adhesion promotion of human mesenchymal stem cells (hMSCs).

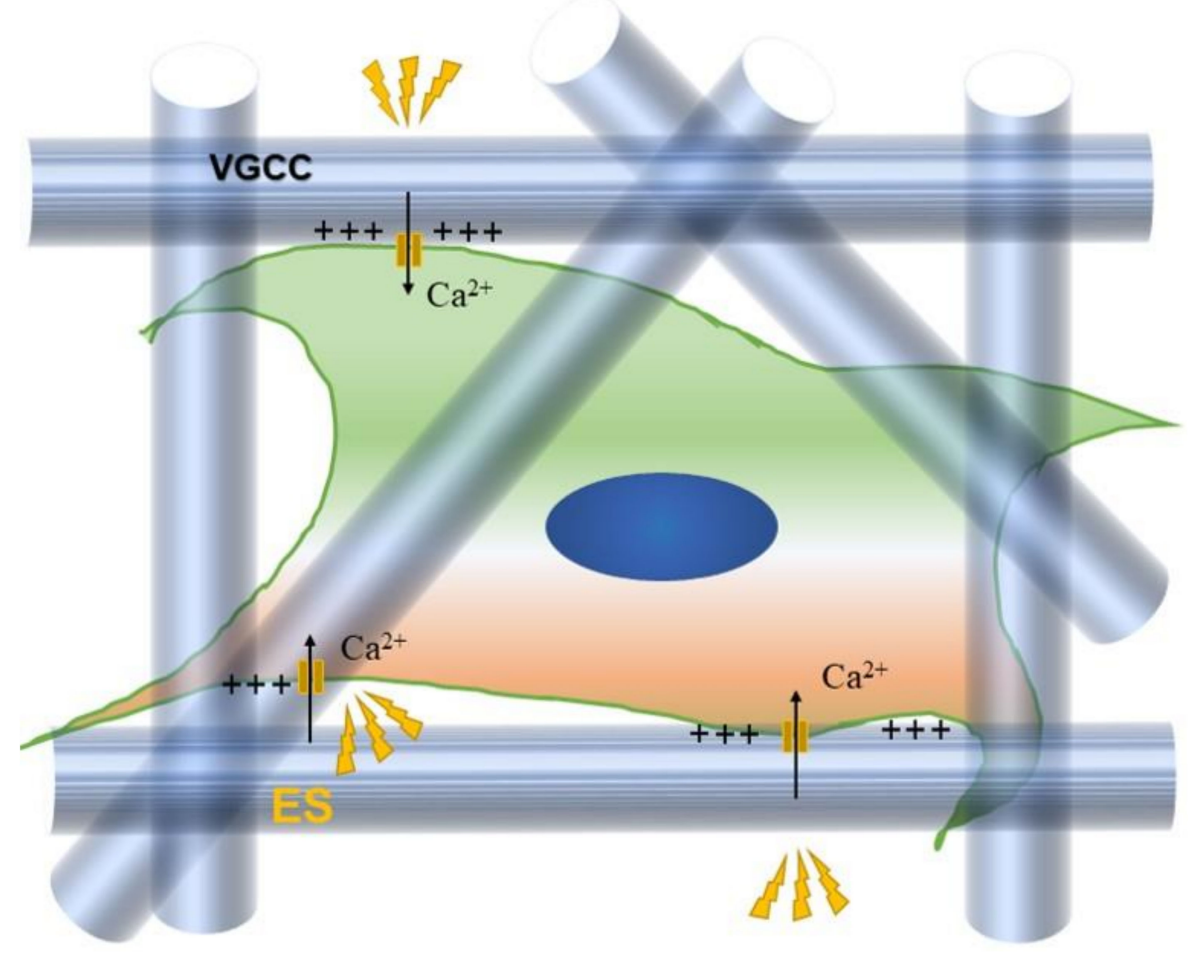

Figure 1. The piezoelectric potential created by piezoelectric electrospun nanofibers stimulates VGCC in the cell membrane and causes cell activation. Reproduced with permission [119]. Copyright (C) 2021, The Royal Society of Chemistry.

The extent of cell-substrate interaction is an important factor in evaluating the effect of the microenvironment of the scaffolds. ECM is composed of structural proteins, polysaccharides, and adhesive proteins [121]. Tissue engineering scaffolds can be also made by the decellularized ECM (dECM). Embedding dECM into synthetic polymers is an effective strategy. The microenvironment enriched with $\mathrm{dECM}$ biochemical cues could stimulate cells to regenerate bone. Choi et al. mixed bone-dECM with PCL and fabricated bioengineered scaffolds by electrospinning which simulated the native environment of tissue [73]. The wettability, water absorption ability, and surface roughness of the scaffold were enhanced by adding bone-dECM. It was shown in alkaline phosphatase (ALP) and gene expression results that bone-dECM affected the osteogenic differentiation. Furthermore, they found that the bone-dECM particle-integrin interaction induced by the cell adhesive proteins regulated the intracellular processes and enhanced the cell adhesion/migration. Junka et al. [61] used sequential electrospinning with PCL solution containing either 
osteoblast or endothelial cells-derived dECM to fabricate two-layer scaffolds. The nanofibrous scaffolds incorporated with angiogenic and osteogenic cues could stimulate bone growth. This work incorporated angiogenic and osteogenic cues into scaffolds to provide the microenvironment that supported osteoblast and endothelial cells in bone regeneration and vascularization. Aside from adding $\mathrm{dECM}$, adding hyaluronic acid or phospholipids can also optimize the microenvironment of the scaffold. Rachmiel et al. [22] combined electrospinning, molecular self-assembly, and molecular recognition motifs to develop a multi-component approach. They followed this approach to fabricate a composite scaffold composed of PCL and hyaluronic acid incorporated with a short self-assembling peptide. The resultant scaffold was similar to the fibrillar structure of ECM in morphology and showed biocompatibility. The results of ALP and degree of biomineralization confirmed that the fibrous scaffold facilitated osteogenic differentiation. $\mathrm{Xu}$ et al. [84] mixed poly (L-lactic acid) (PLLA) and lecithin to fabricate fibrous scaffolds, which offered a strategy for tissue engineering. To improve hydrophilicity and cytocompatibility of PLLA scaffolds, bioactive lecithin was incorporated into polymer solution. PLLA/lecithin scaffolds made a great interaction with cells which induced cells on scaffolds to maintain morphological shape and integrate with the fibers to build a 3D network. Nanoscale building blocks mixed into polymer solution could change the function and shape of fibers in order to meet the application requirements of various fields [122-125]. Wu et al. [126] combined electrospinning with doping to fabricate molybdenum disulfide $\left(\mathrm{MoS}_{2}\right)$ composite nanofibrous scaffolds. The $\mathrm{MoS}_{2}$ composite scaffolds gave cells the platform to maintain activity and provided positive promotion to regulate cell proliferation and osteogenic differentiation. Sergi et al. [70] fabricated PCL scaffolds doped with bioactive glasses. In order to enhance the cell response to the fibrous scaffolds, they embedded bioactive glasses with different compositions into the matrix, and the results showed that the composite scaffold had higher abilities in cell adhesion and proliferation compared with neat PCL scaffolds.

In addition to scaffold components, the topographic structure is also a key factor to mimic ECM for scaffolds [127]. By combining the advantages of polylactic acid (PLA) and chitosan, $\mathrm{Xu}$ et al. [86] prepared a bicomponent scaffold with island-like structure (Figure 2). Automatic phase separation between two incompatible polymers happened during the electrospinning process. With the quick speed of evaporation of structure under a high temperature in jets, there was not enough time for chitosan molecular chain migrating to the surface of electrospun jets to cover the fibrous shell, which resulted in the formation of the intermittent islands structure. Chitosan island-like structure provides a controllable balance of the surface hydrophilicity and hydrophobicity, suitable roughness at the surface for cell adhesion and cell recognition sites. This work presented a novel scaffold surface design.

Although the temperature of jets affects the surface of scaffolds, the electrospinning method to control mesh architecture and composition could also establish a specific ECM for scaffolds. Wang et al. [45] designed multifunctional scaffolds by controlling the speed of electrospinning solution during co-spinning progress (Figure 3). They set PCL as the outer face to provide mechanical strength and gelatin loaded with hydroxyapatite (HAP) as the inner face to provide cell affinity and osteoconductivity. From the outer to the inner, the content of PCL decreased while the content of gelatin increased. The fiber diameter and alignment affect interaction of the scaffold with cells [128-130]. Based on earlier work, Xie et al. [42] designed a group of controlled experiments. The results verified that alignment and decreased diameter of fibers had clear advantages in promoting proliferation and migration and facilitating the osteogenic differentiation of bone marrow mesenchymal stem cells (BMSCs) compared with normal fibers. Scaffolds with random structure prevent effective cell infiltration. Therefore, to overcome this disadvantage of traditional electrospinning, Jordahl et al. [41] created a modified electrospinning process called 3D jet writing. This modified process was demonstrated to create precisive 3D structures to offer customizable pore geometries (Figure 4). Precisive structures are achieved via stable 
jetting supported by a secondary electrode. Compared with a conventional process, this work reported a novel process to fabricate precisive scaffolds.

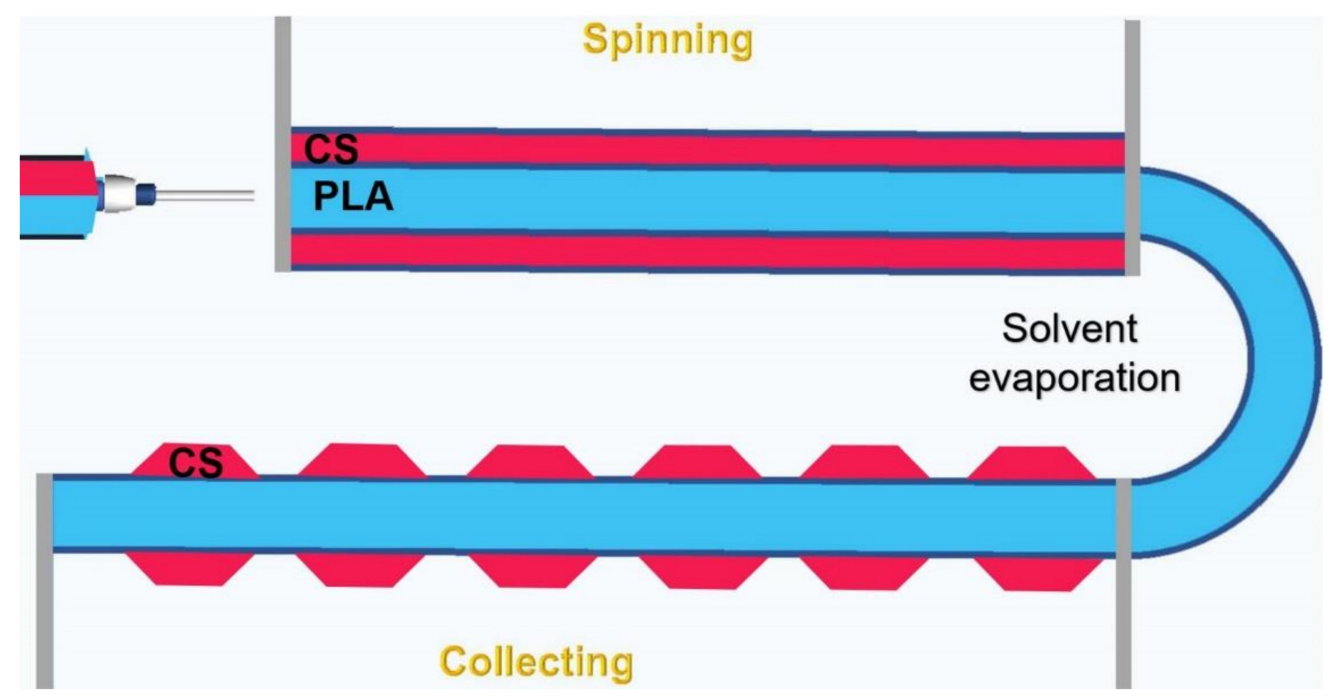

Figure 2. The illustration of preparation of a bicomponent scaffold with island-like structure formed from PLA and chitosan (CS). Reproduced with permission [86]. Copyright (C) 2021, American Chemical Society.

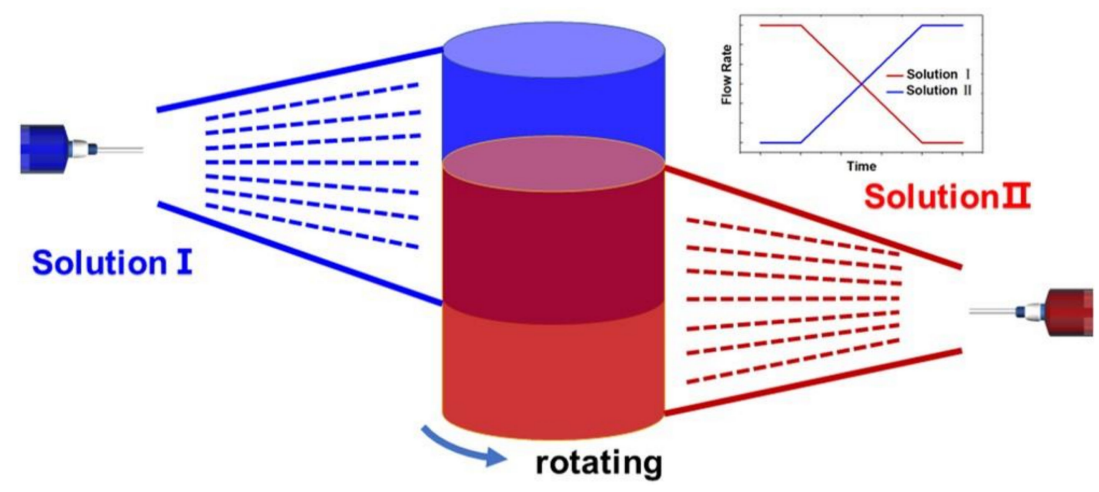

Figure 3. Preparation of multifunctional scaffolds via controlling the speed of electrospinning solution during co-spinning progress. Reproduced with permission [45]. (c) 2021 Wiley-VCH GmbH.

(a)

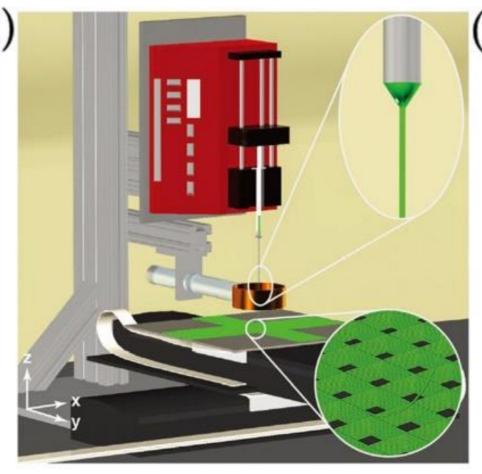

(b)

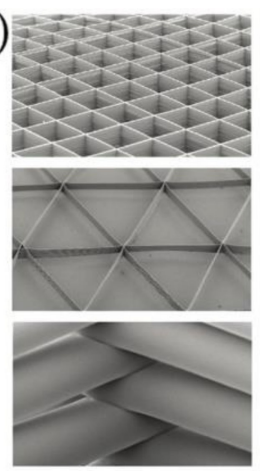

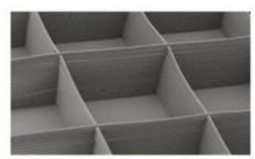
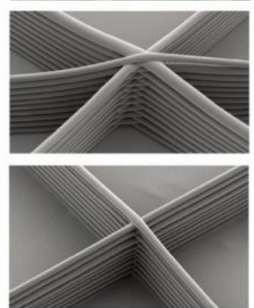
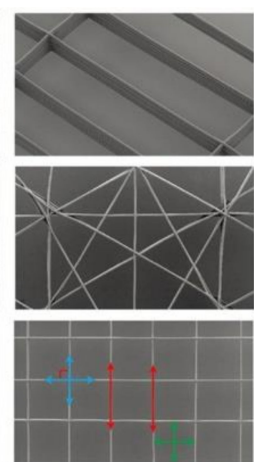

Figure 4. (a) The illustration of the 3D jet writing setup; (b) the SEM image of the fibrous scaffolds made by 3D jet writing. Reprinted from [41], with permission from Wiley. (c) 2021 WILEY-VCH Verlag GmbH \& Co. KGaA, Weinheim.

In general, the scaffold built by electrospinning has a native ECM-like physical structure with high surface area. However, limited pore sizes are the obstacles for cell infiltration 
to the scaffold [131]. Various strategies were employed to modify the surface of electrospun scaffolds. It was reported that HAP crystals could be bound to the acidic amino acid peptide domains [132]. Based on early study, Luo et al. [105] prepared the silk fibroin (SF)/PCL scaffolds and immersed them in simulated body fluid to mineralize the scaffolds. As the seven amino acid glutamate sequence (E7) could improve peptide coupling to HAP [133], they coupled mineralized scaffolds with E7-BMP-2. Aside from this method, Li et al. [58] used NHS-EDC (NHS, N-hydroxysuccinimide; EDC, 1-ethyl-3-(3-dimethylaminopropyl) carbodiimide) amide reaction to couple E7-BMP-2 onto the PCL scaffolds. The results of these two works showed that modified scaffolds had a better performance in cell adhesion than unmodified ones. To improve the ability of the scaffold for modulating human pluripotent stem cells (hPSCs) differentiation toward osteoblastic phenotype, Deng et al. [63] also combined electrospun PCL scaffold with vitronectin (VN) peptide conjugation via NHS-EDC amide reaction. It was reported previously that PLLA fibrous scaffold with high surface area was fabricated by a two-step strategy [134,135]. Based on this strategy, Lu et al. [30] fabricated porous PLLA/dopamine (DOP)/amorphous silica nanoparticles (SiNPs) scaffolds with high surface area (Figure 5). DOP was applied to modify the surface of PLLA fiber and provided active functional groups. The interaction between PLLA fibers and silica nanoparticles (SiNPs) was enhanced by covalent and non-covalent bonding from polydopamine (PDA), which was made from DOP via oxidative self-polymerization. It not only improved the mechanical properties and hydrophilicity of PLLA/DOP/SiNP hybrid scaffolds, but also enhanced the biocompatibility of the scaffolds. The scaffolds showed great biocompatibility and abilities of cell adhesion and proliferation. It is known that native ECM includes collagen, laminin and glycosaminoglycans, and these macromolecules could be physically absorbed or chemically conjugated onto scaffolds for improving bioactivity [136]. Xu et al. [54] cultured Rabbit articular chondrocytes (rACs) on PCL scaffolds, then generated dECM-coated PCL scaffolds through decellularization treatment. With native ECM macromolecules, the scaffolds had a great effect on cartilage tissue repair. Moreover, in order to mimic the morphological trait and chemical composition of ECM, Yang et al. produced HAP/collagen (Col)-coated poly (lactic-co-glycolic acid) (PLGA) scaffolds via an electrospinning and biomimetic process [97]. In vitro experiment and ALP activity results demonstrated that $\mathrm{HAP} / \mathrm{Col}$ coating layer improved the interaction between cells and scaffolds. 3D printing has been applied in producing scaffolds for tissue regeneration [137]. Compared with other approaches, 3D printed scaffolds have many advantages including flexibility in design, capability of generating specific shapes, and making highly precisive pores. Li et al. [50] combined the advantages of both electrospinning and 3D printing, and the fibrous scaffolds prepared by electrospinning were successfully covered onto the surface of 3D printed scaffolds. They reported a simple and versatile method to decorate $3 \mathrm{D}$ printed scaffolds with bioactive electrospun fibrous segments.

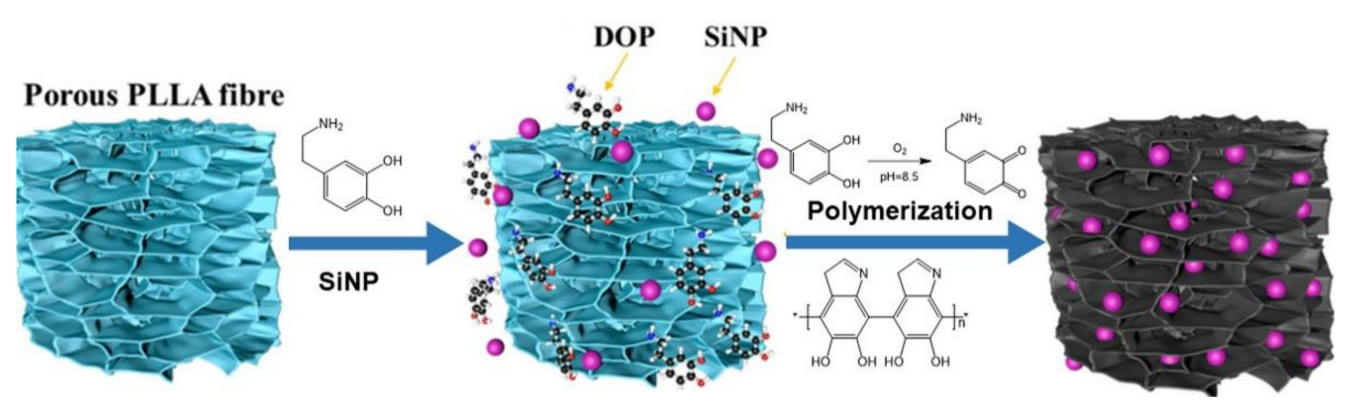

Figure 5. The surface of PLLA fiber is modified by DOP. With polymerization of PDA made from DOP via oxidative self-polymerization, the interaction between PLLA fibers and SiNPs is built. Reprinted from [30], with permission from Elsevier. (C) 2021 Elsevier B.V. All rights reserved.

Three-dimensional structure scaffold necessitates an interconnected network and a stable framework. A 3D porous scaffold with the characteristics of open cellular structure, 
reversible compression, and controllable shape was fabricated by Chen et al. via electrospinning and freeze drying [82]. In order to establish a network structure, crosslinking is essential. Instead of glutaraldehyde, they chose citric acid as a crosslinking agent based on its characteristics of biocompatibility and nontoxicity. Citric acid plays a key role in inducing and stabilizing the growth of HAP during mineralization. As expected, the 3D porous PLA/regenerated cellulose scaffold with high biological activity possessed both dual porous structure and dimensional stability. On the other hand, Fong and Sun developed an approach to build 3D electrospun fibrous scaffolds named thermally induced nanofiber self-agglomeration (TISA) [138]. Briefly, 3D electrospun fibrous scaffolds were made from short individual nanofibers converted from electrospun fibers (Figure 6). In addition, Yao et al. [29] combined the TISA technique and freeze-drying method to prepare 3D electrospun PCL/PLA nanofibrous scaffolds. Compared with 3D electrospun PCL nanofibrous scaffolds, PCL/PLA-3D scaffolds improved the cell viability and osteogenic differentiation of hMSCs. Based on this work, Xu et al. [56] explored the effect of content of PLA on the properties of PCL/PLA-3D scaffolds. With the increase of PLA content, stiffness and bioactivity were improved, which resulted in the increase of the ALP activity, calcium content, and gene expression level.

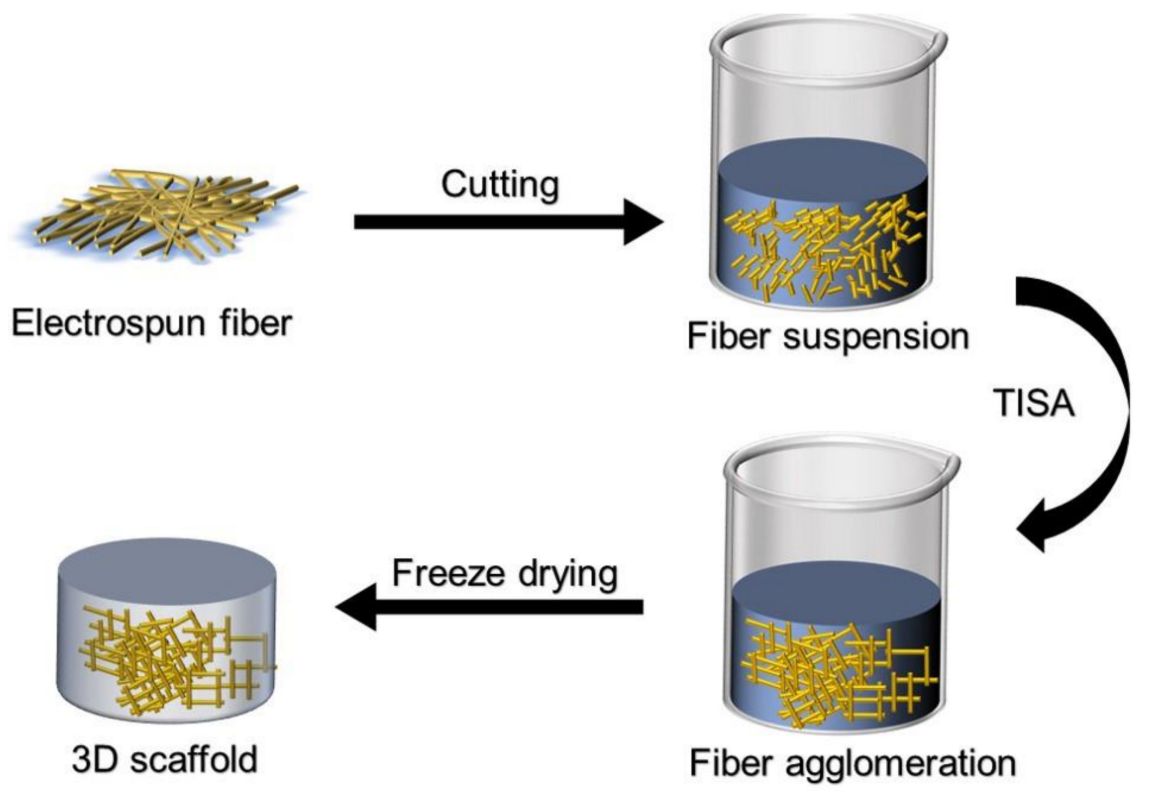

Figure 6. The illustration of building $3 \mathrm{D}$ electrospun fibrous scaffold via TISA and freeze drying $[29,56,139]$.

Furthermore, Hwang et al. reported a 3D electrospinning technique to create 3D PLA scaffolds with the support of lactic acid (LA) [92,139]. Then, they synthesized calcium lactate $(\mathrm{CaL})$ by recycling the $\mathrm{LA}$ component that induced the formation of the 3D bioactive PCL/CaL fibrous scaffold [66]. Incorporation of CaL enhanced the biocompatibility and the tensile properties of the scaffold. This 3D scaffold exhibited excellent performance in biomineralization, cell infiltration, and proliferation with MC3T3-E1.

\section{Mechanical Support}

Ideally, BTE scaffolds could not only mimic natural ECM, but also provide appropriate mechanical support for new bone formation. Polymeric materials are considered a promising candidate with mechanical properties similar to tissue for temporary support of bone regeneration. The electrospinning technique has been employed to easily customize the scaffolds with special structures and mechanical properties by changing scaffold components and electrospinning process. 
One advantage of electrospinning is that spinning solution can be easily customized. Electrospinning solutions can be easily mixed with nanomaterials for reinforcing resultant electrospun nanofibers, such as nanoparticles [51,59,100], nanosheets [32], etc. These nanomaterials are evenly dispersed in the electrospun matrix and the interface combination with matrix is established, which can effectively transfer the external force from the matrix. Moreover, several polymers with excellent mechanical properties have been utilized in electrospinning solutions for BTE scaffolds. Polytetrafluoroethylene (PTFE) is known for its high fracture toughness [140], but its lack of spinnability remains a challenge. Park et al. [141] prepared a polyethylene oxide (PEO) solution containing PTFE dispersion for electrospinning. The use of PEO effectively improved PTFE spinnability and then PEO was removed by sintering process. Furthermore, previous studies reported that shape memory BTE scaffolds provided mechanical support while offering in situ mechanical stimulus for efficient bone regeneration [142]. For example, PLLA was used as a shape memory polymer and then modified to enhance its shape memory functionality [143-145]. Wang et al. [85] fabricated PLLA electrospun BTE scaffold incorporated with PHBV for improvement of mechanical properties and shape memory functionality. Their study revealed that this improvement decreased the transition temperature of PLLA fibers owing to incorporated PHBV.

Different electrospinning methods have been explored for preparing BTE scaffolds for mechanical support. Tao et al. fabricated core-sheath structured fibrous scaffolds by coaxial electrospinning. Mechanical testing showed that the core-sheath scaffolds displayed better mechanical properties compared to those of single-component scaffolds [19]. In addition, core-sheath structure can also be obtained by double conjugate electrospinning (Figure 7). Different from coaxial electrospun fibers, core-sheath yarns endowed with suitable mechanical properties for producing a fabric were generated by this method. Gao et al. [107] developed PLA/tussah silk fibroin (TSF) nanofiber yarns by double conjugated electrospinning, and then the yarns were woven into multilayer fabrics as BTE scaffolds. Compression tests revealed that the multilayer fibrous fabric scaffolds showed significant superiority in compressive strength compared to the non-woven fibrous mats. Furthermore, Xie et al. used the same method to prepare nanofiber yarns with different contents of HAP for fabrication of gradient woven fabric scaffolds [146]. Experimental results showed that the prepared scaffolds exhibited excellent mechanical properties while providing a mineral gradient graft for tendon-to-bone tissue interface regeneration.

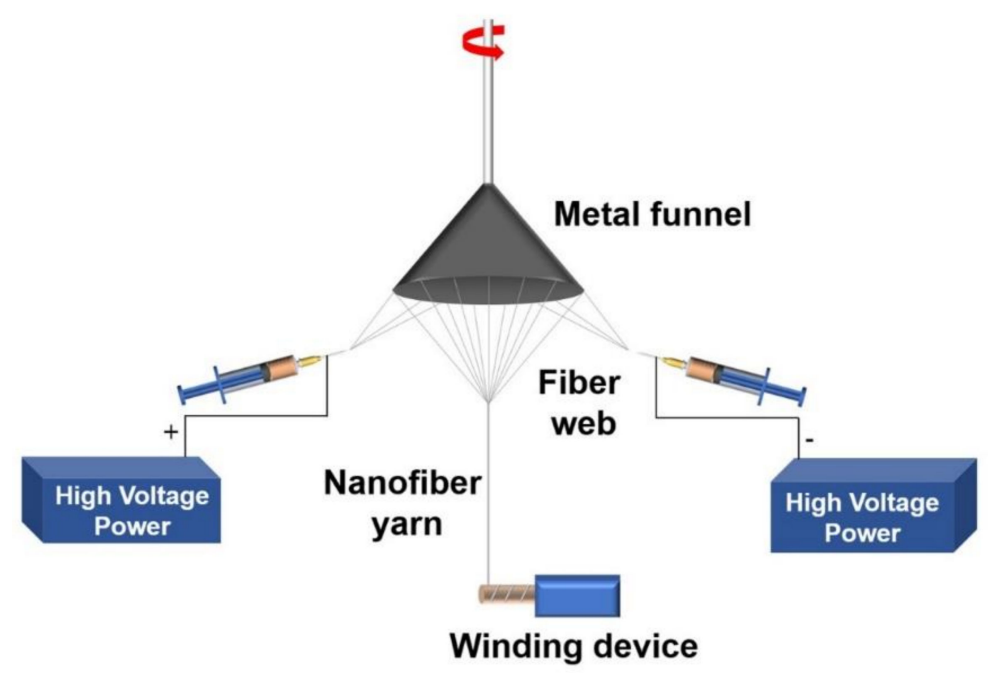

Figure 7. The illustration of core-sheath yarns endowed with suitable mechanical property for producing a fabric. The fiber web is drawn by an insulating rod placed in center of funnel, and then forms a fibrous cone which is twisted by rotating funnel to form continuous yarns [107]. 
Multilayer or hierarchical structure shows its potential of providing mechanical support for BTE. It is simple to prepare the scaffolds with hierarchical structure by folding electrospun mats several times [147] or bonding them layer by layer with adhesive [52] Inspired by the complex structure of natural bone tissue, previous works reported their novel approaches to designing hierarchical scaffolds. Hoener et al. [16] prepared coaxial electrospun fibrous layers with different core size by adjusting the ratio of core/sheath solution flow rates, and then the strain gradient scaffold was obtained. In vitro study revealed that multiphenotypic differentiation of hMSCs depended on the local compressive strains. The prepared scaffolds provided a novel gradient platform for osteochondral tissue regeneration. To mimic the complex fiber orientation in native cartilage, Munir et al. [68] prepared electrospun fibers with random orientation and alignment as well as cryo-printed helix to fabricate a multilayer scaffold. The prepared scaffolds possessed compressive properties for matching natural cartilage.

Moreover, crosslinking agents have been employed for improvement of mechanical properties of electrospun polymeric fibers by enhancing links among polymer chains. For example, genipin is a biocompatible crosslinking agent and has been widely used to provide chemical crosslinking in BTE scaffolds [148]. Ren et al. [108] employed genipin as a crosslinking agent for fabricating electrospun PLA/gelatin nanofibers. UV light has also been used for crosslinking network formation. Yang et al. [149] prepared electrospun biomimetic periosteum incorporating methacrylated gelatin (GelMA), l-arginine-based unsaturated poly (ester amide) (Arg-UPEA), and methacrylated hydroxyapatite nanoparticles (nHAMA). Exposed under UV light, the organic-inorganic network inside the fibers was formed and the mechanical strength was enhanced.

\section{Drug Delivery System}

Drugs (e.g., therapeutic agents, growth factors, non-viral genes, etc.) could promote new bone formation and prevent inflammation [150]. Electrospun fibers are regarded as drug carriers that direct cell adhesion and differentiation by delivering drugs. Hence, a variety of strategies were proposed to design drug delivery systems by functionalizing electrospun fibrous scaffolds.

Owing to the adjustable degradation rate and interconnected porous structure, electrospun polymeric nanofibers have been employed to load drugs. By adding drugs in polymer solution, drugs are directly encapsulated in electrospun polymeric nanofibers. Abazari et al. [90] prepared electrospun PLLA/poly(3-hydroxybutyrate) (PHB) nanofibers incorporated with curcumin and investigated the curcumin release profile in vitro. Experimental results showed the continuous release of curcumin during 14 days and improvement of the expression level of osteogenic gene markers, which confirmed the effect of curcumin on the osteogenic differentiation of human adipose-derived stem cells (ADSCs). Moreover, some drugs are considered antibacterial agents for inhibiting implant related infections. For example, rifampicin (Rf) is a major drug widely used for treatment of bone infections, exhibiting broad-spectrum antibacterial activity $[151,152]$. In a study by Kiran et al., Rf was loaded in electrospun PCL/HAP nanofibers by mixing with polymer solution for preparing antibacterial BTE nanofibers [55]. Their drug release study particularly revealed an initial burst release of Rf due to the porous structure, which could prevent early infection when nanofibers were implanted.

The synergistic effect of multiple growth factors is required because of the complicated process of bone formation. Therefore, it is important to design a multiple delivery system for mimicking the natural microenvironment, effectively promoting bone regeneration and vascularization. Many groups reported their strategies to deliver two or more drugs. For example, Wang et al. developed a tricomponent delivery scaffold incorporating recombinant human BMP-2 (rhBMP-2), recombinant human vascular endothelial growth factor (rhVEGF), and calcium phosphate nanoparticles by co-electrospinning (Figure 8) [46]. In vitro study revealed that rhBMP-2 and rhVEGF were sequentially released to promote both bone regeneration and vascularization. Furthermore, in their recent study, the os- 
teogenesis and angiogenesis properties of co-electrospun tricomponent scaffolds were evaluated in vivo, which showed enhancement of new bone formation in mouse cranial defect model [153]. However, it was noticed that unsuitable doses and inappropriate kinetics of drugs adversely affect bone regeneration [154,155].

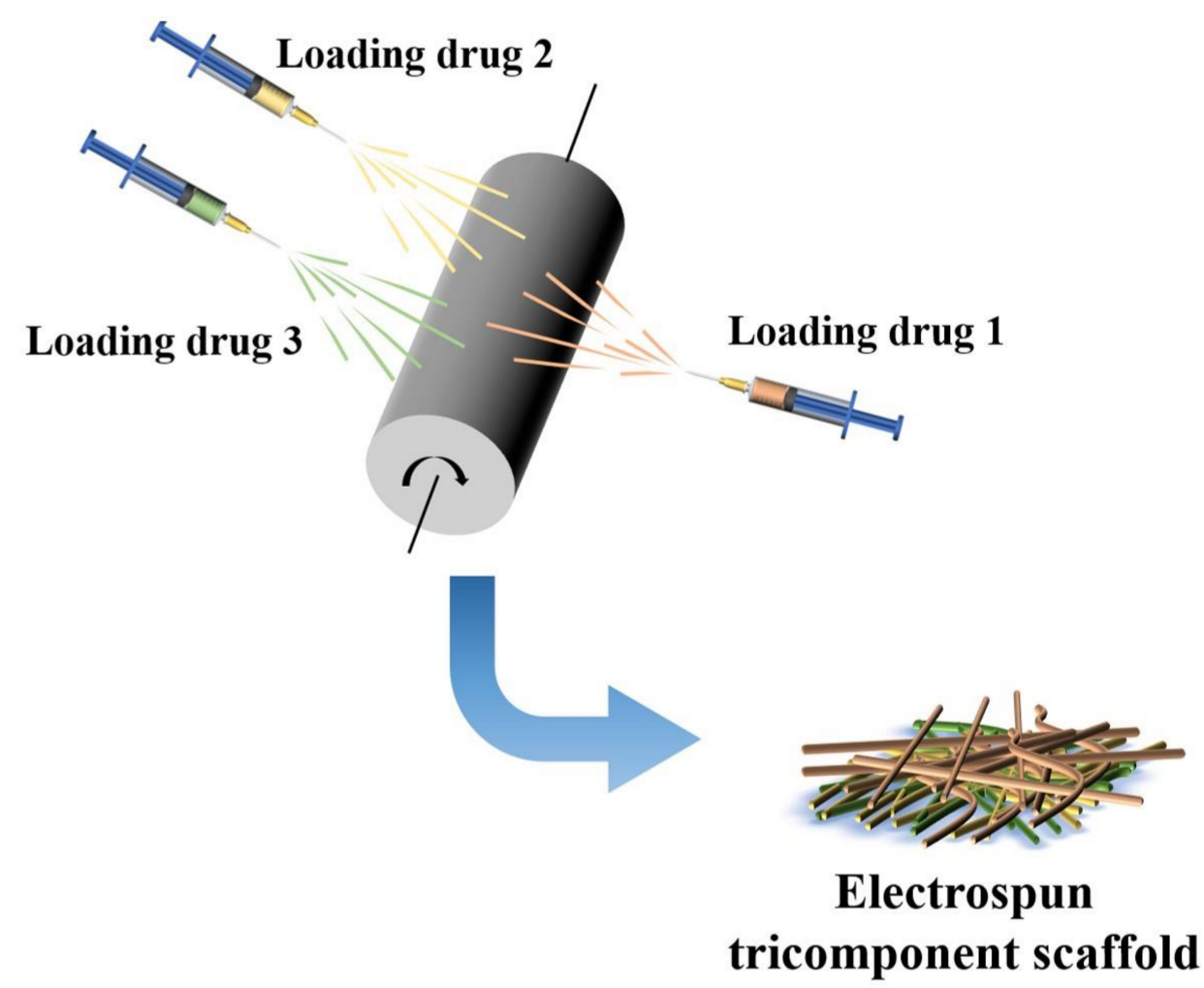

Figure 8. The illustration of a tricomponent delivery scaffold incorporating rhBMP-2, rhVEGF. and calcium phosphate nanoparticles by co-electrospinning. Reproduced with permission [46]. Copyright (C) 2021, The Royal Society of Chemistry.

Although many studies confirmed that drugs could be easily blend into electrospun fibers, the initial burst release and uncontrollable release may occur. Thus, the delivery of drugs should be appropriately controlled to match the physiological feature of bone regeneration. To solve this problem, drug carriers (e.g., nanoparticles, microsphere, etc.) are incorporated into electrospun scaffolds (Figure 9). Zhu et al. [27] loaded N-acetyl cysteine (NAC) onto mesoporous silica nanoparticles (MSNs) by simple immersing process and fabricated electrospun NAC@MSNs/PLGA scaffold. In vitro release and cellular studies showed that the fabricated delivery system provided a sustained release of NAC with high concentration, which affected the osteogenic differentiation of rat bone marrow-derived stroma cell (rBMSC). Furthermore, MSNs were utilized by Wang et al. to load alendronate (ALN), a drug to inhibit osteoclastic bone resorption [71]. Silicate is the degradation product of MSNs. As the ALN-loaded MSNs was released from the electrospun fibers, silicate and ALN affected bone formation and bone resorption respectively, achieving a dual regulation of bone regeneration. 


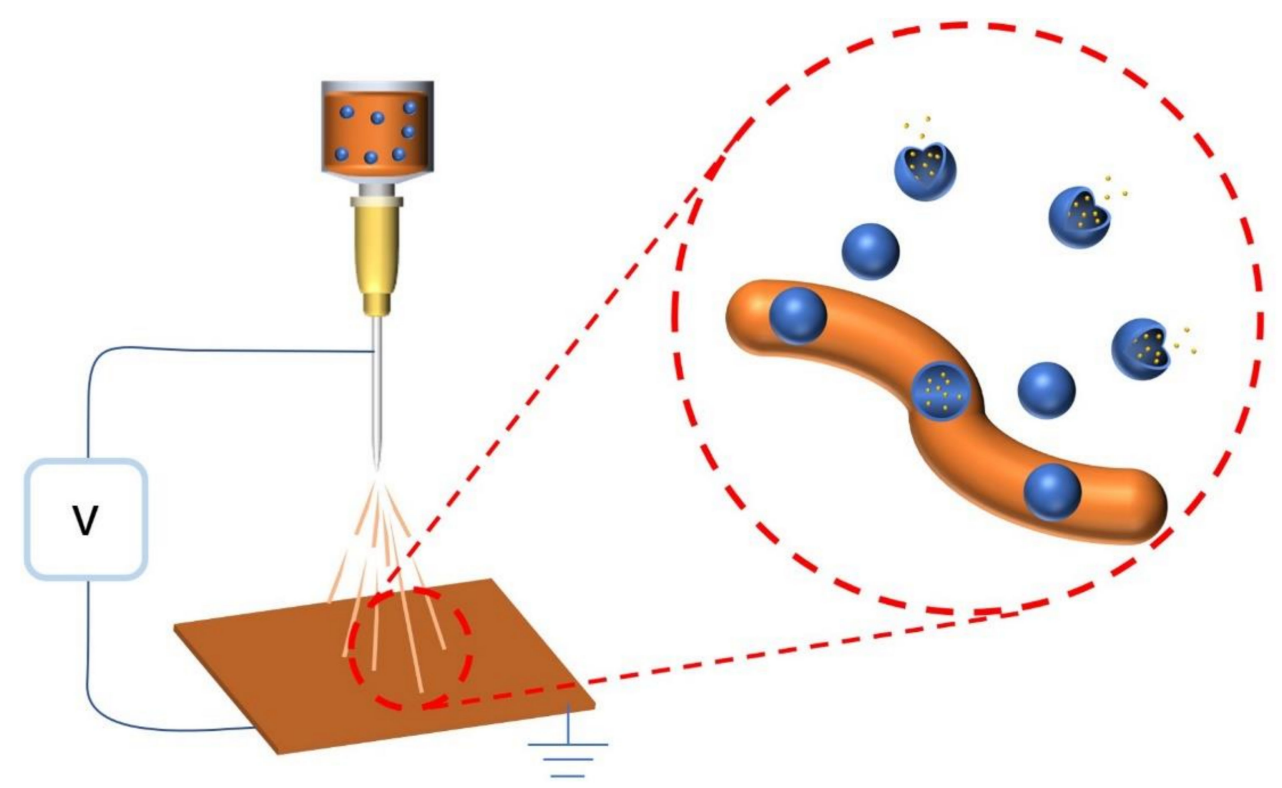

Figure 9. Electrospun fibrous drug delivery system made by simply immersing drug carriers [27].

Apart from the blending process, several researchers reported their attempts on the surface chemistry of electrospun fibers. Drug carriers can be immobilized onto the modified surface for maximize utilization of the high specific surface area of fibers (Figure 10). M. Mohammadi et al. [81] modified electrospun PLA fibrous scaffold by surface grafting, and then BMP-2 peptide-loaded liposomes were immobilized. As observed by confocal laser scanning microscopy, the prepared scaffolds showed higher attachment efficiency of liposomes compared to those not modified.

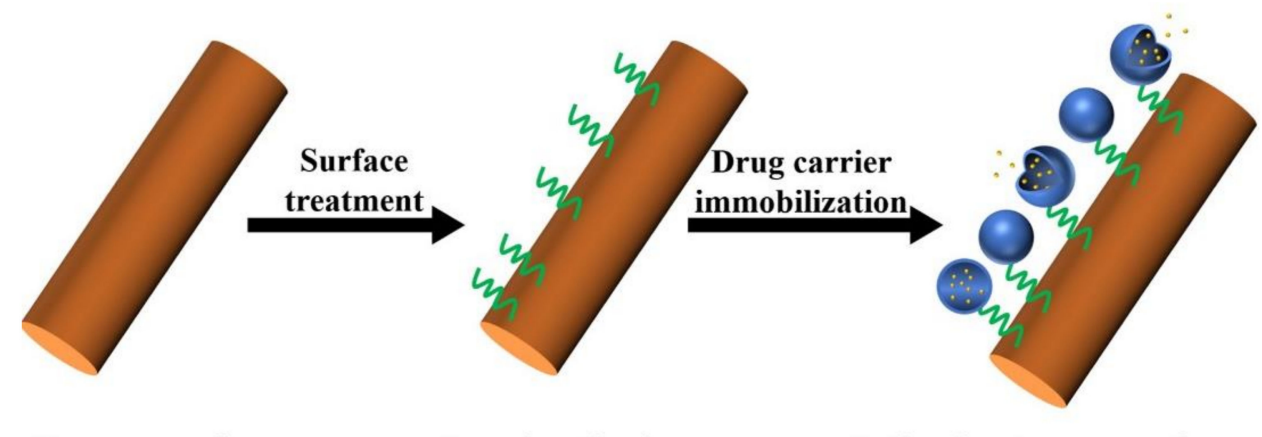

Electrospun fiber

Functionalization

Delivering drug on surface

Figure 10. Electrospun fibrous drug delivery system built by immobilizing drug carriers onto the modified surface [81].

For further improvement of the effect of delivered drugs, the fabrication of drugloaded carriers can be optimized by several technique. Microfluidic (MF) technique was selected to produce drug-loaded carriers with desired size and excellent cell viability. For example, Doosti-Telgerd et al. [93] prepared polyplexes nanoparticles loading BMP-2 plasmid DNA through MF platform (Figure 11). Compared to bulk prepared drug-loaded carriers, those fabricated by MF platform showed lower toxicity and higher cell viability due to the fine mixing reaction based on molecular diffusion. In addition, Aragon et al. [11] proposed combination of electrospinning and electrospraying for fabrication of fibrous scaffolds decorated with PLGA-BMP-2 particles (Figure 12). As a simple and low-cost approach, electrospraying can be used to prepare drug-loaded nanoparticles without significant phase separation, ensuring a stable release during bone regeneration [11]. 


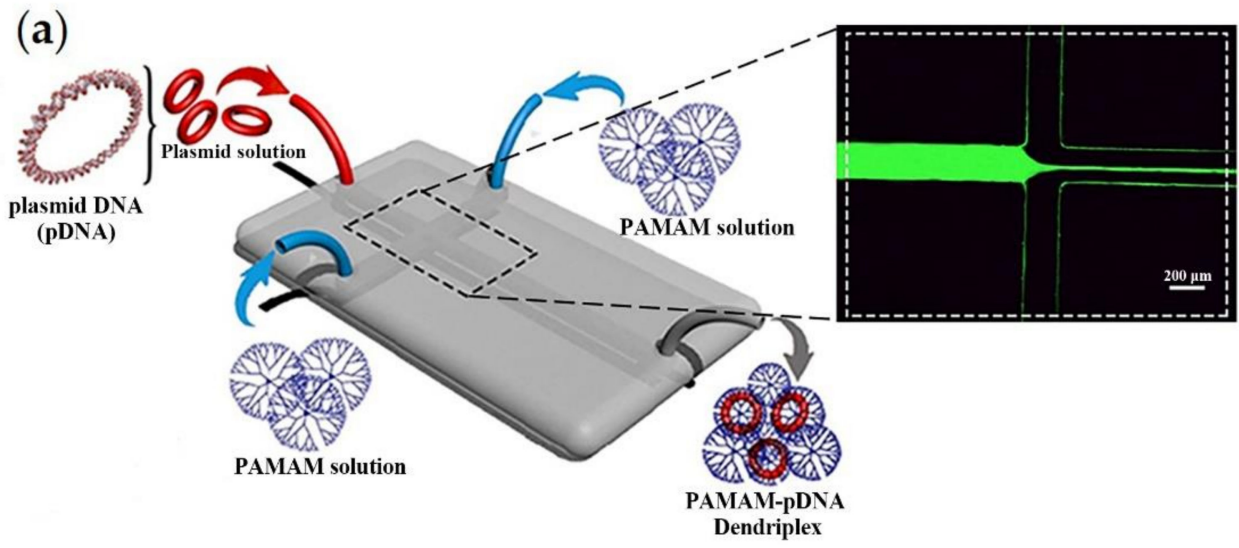

(b)
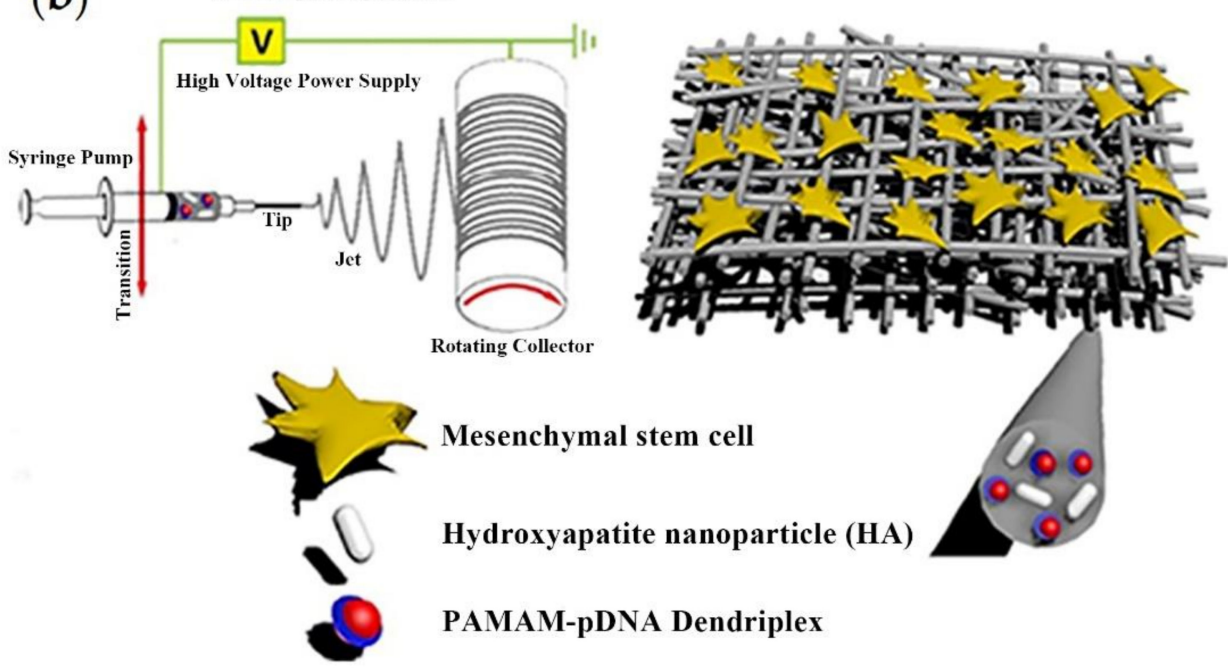

Mesenchymal stem cell

Hydroxyapatite nanoparticle (HA)

PAMAM-pDNA Dendriplex

Figure 11. (a) Schematic representation of MF preparation of drug-loaded carriers and (b) scaffolds fabrication. Reprinted from [93] with CC-BY license. Copyright @ 2021 Doosti-Telgerd et al.

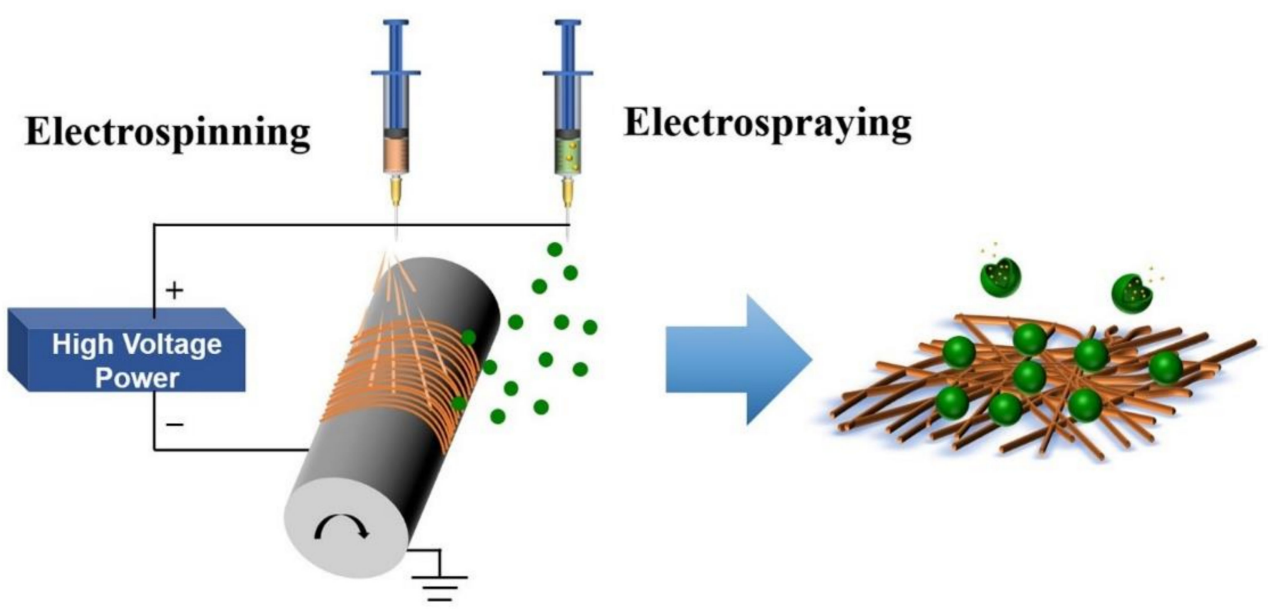

Figure 12. Fibrous drug delivery system prepared by electrospinning and electrospraying. Reproduced with permission [11]. (c) 2021 Elsevier Inc. All rights reserved.

Moreover, by designing and optimizing electrospinning process, the corresponding microstructure can be obtained to customize the desired drug release model. Coaxial electrospinning provides a strategy to fabricate core-shell structure nanofibers as a drug delivery system. It was reported that coaxial nanofibers exhibited lower release rates compared to that of uniaxial nanofibers, resulting in a prolonged release [156]. Recently, 
various drug delivery systems fabricated by coaxial electrospinning were reported. Generally, drugs are loaded in the core of coaxial nanofibers and continuously released for inducing bone regeneration $[12,14,20,21]$. However, a few examples were reported in which the outer shell encapsulated drugs while the inner core part acted as mechanical support [19]. In order to achieve desired release pattern, several attempts focused on optimizing the structure of coaxial nanofibers. For example, Huang et al. [67] developed BMP-2 loaded core-shell nanofibers with shish-kebab (SK) structure on the surface (Figure 13). After electrospinning, the prepared nanofibers were immersed in PCL solution and SK structure was obtained by polymer chain crystallization in a folded and periodic fashion with solvent evaporation. An in vitro drug release study showed that the SK structure nanofibers provided a gentler release than those of coaxial nanofibers without SK structure. Gong et al. [17] incorporated redox-responsive nanogels into the outer shell of prepared coaxial nanofibers (Figure 14). The disulfide bonds of nanogels linked or disconnected under different concentration of glutathione (GSH), leading to the establishment or disappearance of nanochannels to release BMP-2. Therefore, the programmed drug delivery process could be achieved by this method.

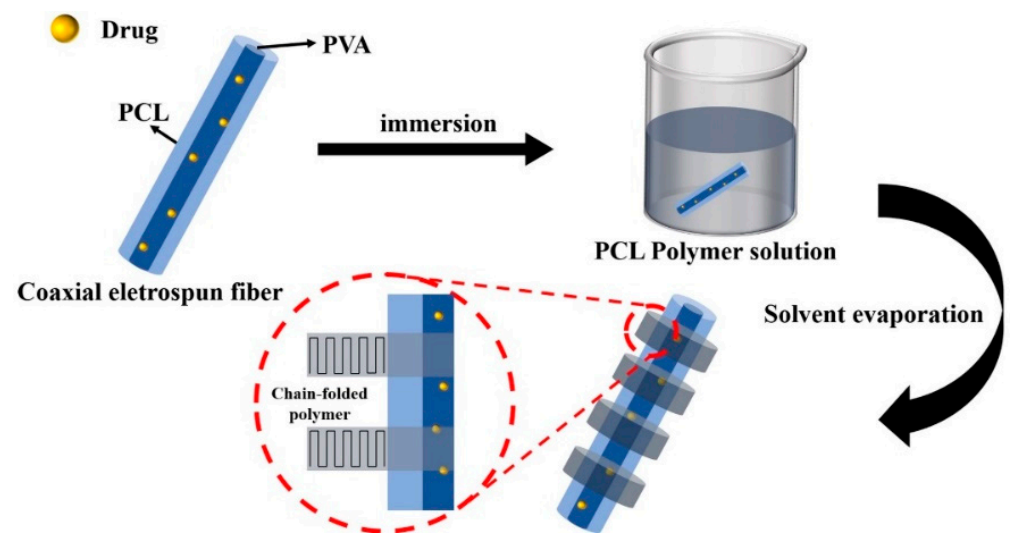

Figure 13. Illustration of the fabrication of the PCL/polyvinyl alcohol (PVA) shish-kebab-structured scaffolds. Reproduced with permission [67]. Copyright $\odot$ 2021, American Chemical Society.

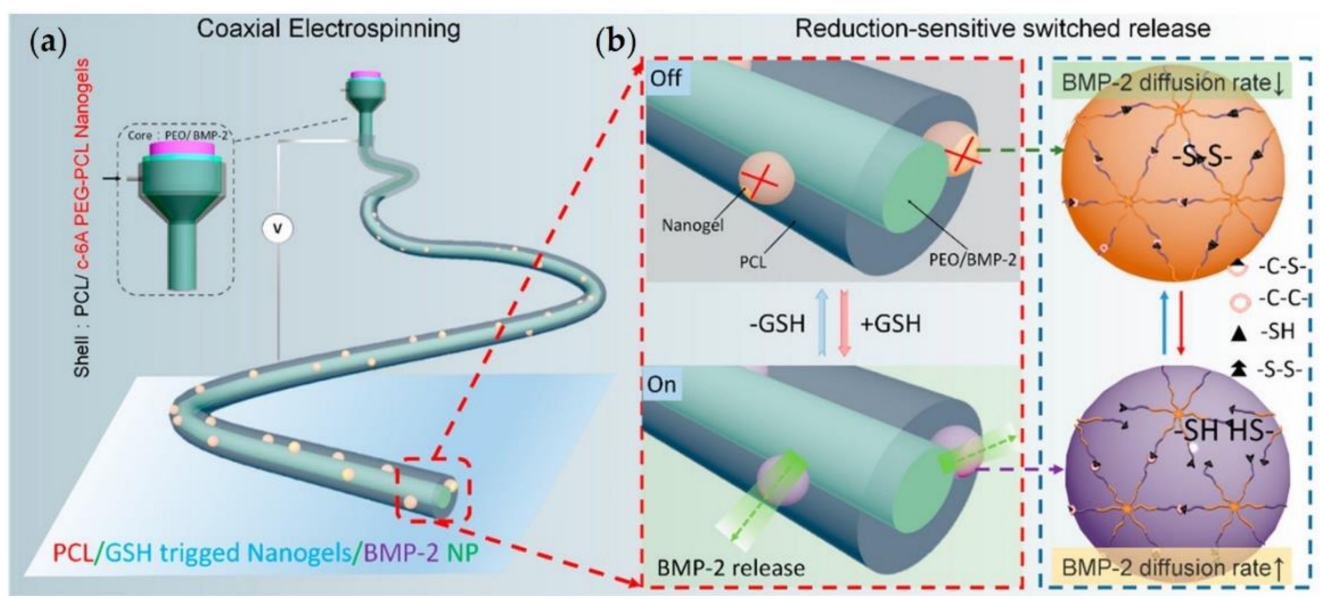

Figure 14. (a) Illustration of the fabrication of nanogel-in-nanofiber device with coaxial electrospinning; (b) schematic representation of the redox-switched release with the nanogel. Reprinted from [17], with permission from American Chemical Society. Copyright (c) 2021, American Chemical Society.

In short, different drug delivery strategies were proposed for controllable and sustainable release, especially for a suitable release rate to match the process of bone regeneration. As mentioned above, drug carriers and optimized fiber structure were both introduced 
to achieve the expected release profile. It should be noted that fine tuning of the release rate remains a challenge. Therefore, introducing stimuli-responsive functions could be considered to fabricate a fibrous scaffold with sensitive and smart drug release feature.

\section{Summary}

The BTE scaffold is required to exhibit excellent biocompatibility, biodegradability, and suitable mechanical properties, which provide an extracellular environment similar to natural ECM. Electrospinning is a simple technique for preparing fibrous scaffolds. The properties of polymers employed in electrospinning are required to be close to natural bone tissue. Meanwhile, electrospinning methods are optimized, and the prepared scaffolds are post-treated in order to effectively simulate bone structures. In addition, significant efforts are made to fabricate electrospun scaffolds with hierarchical structures in order to improve mechanical properties similar to those of bone tissue. Moreover, a drug delivery system is introduced in scaffold fabrication, which effectively reduces the time of bone tissue repairing and the biodegradation period of scaffolds. However, the application of electrospun scaffolds in BTE remains a great challenge and further improvement of the properties of electrospun scaffolds is still under exploration, which might shed new light on their applications in BTE.

Author Contributions: Conceptualization, Y.H. and Q.S. (Qian Sun); investigation, C.Y. and Q.S. (Qi Shao); resources, Y.H.; writing-original draft preparation, C.Y. and Q.S. (Qi Shao); writingreview and editing, C.Y., Q.S. (Qi Shao), L.H., Q.L., Q.S. (Qian Sun), and Y.H.; visualization, C.Y. and Q.S. (Qi Shao); supervision, Q.S. (Qian Sun), Y.H. and S.R.; project administration, Q.S.(Qian Sun), Y.H. and S.R.; funding acquisition, Y.H. and Q.S. (Qian Sun). All authors have read and agreed to the published version of the manuscript.

Funding: This study was supported by grants from the Shenzhen Fundamental Research Program (Grant no. JCYJ20170818140058675, JCYJ20170818140127741), Natural Science Foundation of Top Talent of SZTU (Grant no. 2019010801010, 2019010801009).

Institutional Review Board Statement: Not applicable.

Informed Consent Statement: Not applicable.

Conflicts of Interest: The authors declare no conflict of interest.

\section{References}

1. Zhang, J.; Liu, W.; Schnitzler, V.; Tancret, F.; Bouler, J.-M. Calcium Phosphate Cements for Bone Substitution: Chemistry, Handling and Mechanical Properties. Acta Biomater. 2014, 10, 1035-1049. [CrossRef]

2. Cabraja, M.; Kroppenstedt, S. Bone Grafting and Substitutes in Spine Surgery. J. Neurosurg. Sci. 2012, $56,87-95$.

3. Moore, W.R.; Graves, S.E.; Bain, G.I. Synthetic Bone Graft Substitutes. ANZ J. Surg. 2001, 71, 354-361. [CrossRef]

4. Li, J.; Sun, H.; Sun, D.; Yao, Y.; Yao, F.; Yao, K. Biomimetic Multicomponent Polysaccharide/Nano-Hydroxyapatite Composites for Bone Tissue Engineering. Carbohydr. Polym. 2011, 85, 885-894. [CrossRef]

5. Beniash, E.; Hartgerink, J.D.; Storrie, H.; Stendahl, J.C.; Stupp, S.I. Self-Assembling Peptide Amphiphile Nanofiber Matrices for Cell Entrapment. Acta Biomater. 2005, 1, 387-397. [CrossRef] [PubMed]

6. Chen, J.-S.; Tu, S.-L.; Tsay, R.-Y. A Morphological Study of Porous Polylactide Scaffolds Prepared by Thermally Induced Phase Separation. J. Taiwan Inst. Chem. Eng. 2010, 41, 229-238. [CrossRef]

7. Yang, F.; Murugan, R.; Wang, S.; Ramakrishna, S. Electrospinning of Nano/Micro Scale Poly(L-Lactic Acid) Aligned Fibers and Their Potential in Neural Tissue Engineering. Biomaterials 2005, 26, 2603-2610. [CrossRef] [PubMed]

8. Thenmozhi, S.; Dharmaraj, N.; Kadirvelu, K.; Kim, H.Y. Electrospun Nanofibers: New Generation Materials for Advanced Applications. Mater. Sci. Eng. B 2017, 217, 36-48. [CrossRef]

9. Frohbergh, M.E.; Katsman, A.; Botta, G.P.; Lazarovici, P.; Schauer, C.L.; Wegst, U.G.K.; Lelkes, P.I. Electrospun HydroxyapatiteContaining Chitosan Nanofibers Crosslinked with Genipin for Bone Tissue Engineering. Biomaterials 2012, 33, 9167-9178. [CrossRef] [PubMed]

10. Smith, L.A.; Liu, X.; Hu, J.; Wang, P.; Ma, P.X. Enhancing Osteogenic Differentiation of Mouse Embryonic Stem Cells by Nanofibers. Tissue Eng. Part A 2009, 15, 1855-1864. [CrossRef] [PubMed]

11. Aragon, J.; Salerno, S.; De Bartolo, L.; Irusta, S.; Mendoza, G. Polymeric Electrospun Scaffolds for Bone Morphogenetic Protein 2 Delivery in Bone Tissue Engineering. J. Colloid Interface Sci. 2018, 531, 126-137. [CrossRef] 
12. Sruthi, R.; Balagangadharan, K.; Selvamurugan, N. Polycaprolactone/Polyvinylpyrrolidone Coaxial Electrospun Fibers Containing Veratric Acid-Loaded Chitosan Nanoparticles for Bone Regeneration. Colloids Surf. B 2020, 193, 111110. [CrossRef]

13. Chen, P.; Liu, L.; Pan, J.; Mei, J.; Li, C.; Zheng, Y. Biomimetic Composite Scaffold of Hydroxyapatite/Gelatin-Chitosan Core-Shell Nanofibers for Bone Tissue Engineering. Mater. Sci. Eng. C 2019, 97, 325-335. [CrossRef] [PubMed]

14. Silva, J.C.; Udangawa, R.N.; Chen, J.; Mancinelli, C.D.; Garrudo, F.F.F.; Mikael, P.E.; Cabral, J.M.S.; Ferreira, F.C.; Linhardt, R.J. Kartogenin-Loaded Coaxial PGS/PCL Aligned Nanofibers for Cartilage Tissue Engineering. Mater. Sci. Eng. C 2020, $107,110291$. [CrossRef] [PubMed]

15. Schilling, K.; El Khatib, M.; Plunkett, S.; Xue, J.; Xia, Y.; Vinogradov, S.A.; Brown, E.; Zhang, X. Electrospun Fiber Mesh for HighResolution Measurements of Oxygen Tension in Cranial Bone Defect Repair. ACS Appl. Mater. Interfaces 2019, 11, 33548-33558. [CrossRef] [PubMed]

16. Horner, C.B.; Maldonado, M.; Tai, Y.; Rony, R.; Nam, J. Spatially Regulated Multiphenotypic Differentiation of Stem Cells in 3D via Engineered Mechanical Gradient. ACS Appl. Mater. Interfaces 2019, 11, 45479-45488. [CrossRef]

17. Gong, T.; Liu, T.; Zhang, L.; Ye, W.; Guo, X.; Wang, L.; Quan, L.; Pan, C. Design Redox-Sensitive Drug-Loaded Nanofibers for Bone Reconstruction. ACS Biomater. Sci. Eng. 2018, 4, 240-247. [CrossRef]

18. Aragon, J.; Navascues, N.; Mendoza, G.; Irusta, S. Laser-Treated Electrospun Fibers Loaded with Nano-Hydroxyapatite for Bone Tissue Engineering. Int. J. Pharm. 2017, 525, 112-122. [CrossRef]

19. Tao, C.; Zhang, Y.; Li, B.; Chen, L. Hierarchical Micro/Submicrometer-Scale Structured Scaffolds Prepared via Coaxial Electrospinning for Bone Regeneration. J. Mater. Chem. B 2017, 5, 9219-9228. [CrossRef]

20. Chi, H.; Jiang, A.; Wang, X.; Chen, G.; Song, C.; Prajapati, R.K.; Li, A.; Li, Z.; Li, J.; Zhang, Z.; et al. Dually Optimized Polycaprolactone/Collagen I Microfiber Scaffolds with Stem Cell Capture and Differentiation-Inducing Abilities Promote Bone Regeneration. J. Mater. Chem. B 2019, 7, 7052-7064. [CrossRef]

21. Huang, Z.; Wang, W.; Wang, Q.; Hojnacki, T.; Wang, Y.; Fu, Y.; Wang, W. Coaxial Nanofiber Scaffold with Super-Active Platelet Lysate to Accelerate the Repair of Bone Defects. RSC Adv. 2020, 10, 35776-35786. [CrossRef]

22. Rachmiel, D.; Anconina, I.; Rudnick-Glick, S.; Halperin-Sternfeld, M.; Adler-Abramovich, L.; Sitt, A. Hyaluronic Acid and a Short Peptide Improve the Performance of a PCL Electrospun Fibrous Scaffold Designed for Bone Tissue Engineering Applications. Int. J. Mol. Sci. 2021, 22, 2425. [CrossRef] [PubMed]

23. Prasad, T.; Shabeena, E.A.; Vinod, D.; Kumary, T.V.; Anil Kumar, P.R. Characterization and In Vitro Evaluation of Electrospun Chitosan/Polycaprolactone Blend Fibrous Mat for Skin Tissue Engineering. J. Mater. Sci. Mater. Med. 2015, 26, 28. [CrossRef]

24. Scaffaro, R.; Lopresti, F.; Maio, A.; Botta, L.; Rigogliuso, S.; Ghersi, G. Electrospun PCL/GO-g-PEG Structures: ProcessingMorphology-Properties Relationships. Compos. Part A 2017, 92, 97-107. [CrossRef]

25. Tao, F.; Cheng, Y.; Tao, H.; Jin, L.; Wan, Z.; Dai, F.; Xiang, W.; Deng, H. Carboxymethyl Chitosan/Sodium Alginate-Based MicronFibers Fabricated by Emulsion Electrospinning for Periosteal Tissue Engineering. Mater. Des. 2020, 194, 108849. [CrossRef]

26. Wu, D.; Samanta, A.; Srivastava, R.K.; Hakkarainen, M. Starch-Derived Nanographene Oxide Paves the Way for Electrospinnable and Bioactive Starch Scaffolds for Bone Tissue Engineering. Biomacromolecules 2017, 18, 1582-1591. [CrossRef] [PubMed]

27. Zhu, Y.; Song, F.; Ju, Y.; Huang, L.; Zhang, L.; Tang, C.; Yang, H.; Huang, C. NAC-Loaded Electrospun Scaffolding System with Dual Compartments for the Osteogenesis of rBMSCs In Vitro. Int. J. Nanomed. 2019, 14, 787-798. [CrossRef] [PubMed]

28. Molnar, K.; Nagy, Z.K. Corona-Electrospinning: Needleless Method for High-Throughput Continuous Nanofiber Production. Eur. Polym. J. 2016, 74, 279-286. [CrossRef]

29. Yao, Q.; Cosme, J.G.; Xu, T.; Miszuk, J.M.; Picciani, P.H.; Fong, H.; Sun, H. Three Dimensional Electrospun PCL/PLA Blend Nanofibrous Scaffolds with Significantly Improved Stem Cells Osteogenic Differentiation and Cranial Bone Formation. Biomaterials 2017, 115, 115-127. [CrossRef]

30. Lu, Z.; Wang, W.; Zhang, J.; Bartolo, P.; Gong, H.; Li, J. Electrospun Highly Porous Poly(L-Lactic Acid)-Dopamine-SiO 2 Fibrous Membrane for Bone Regeneration. Mater. Sci. Eng. C 2020, 117, 111359. [CrossRef]

31. Baldwin, J.G.; Wagner, F.; Martine, L.C.; Holzapfel, B.M.; Theodoropoulos, C.; Bas, O.; Savi, F.M.; Werner, C.; De-Juan-Pardo, E.M.; Hutmacher, D.W. Periosteum Tissue Engineering in an Orthotopic In Vivo Platform. Biomaterials 2017, 121, 193-204. [CrossRef]

32. Awasthi, G.P.; Kaliannagounder, V.K.; Park, J.; Maharjan, B.; Shin, M.; Yu, C.; Park, C.H.; Kim, C.S. Assembly of Porous Graphitic Carbon Nitride Nanosheets into Electrospun Polycaprolactone Nanofibers for Bone Tissue Engineering. Colloids Surf. A 2021, 622, 126584. [CrossRef]

33. Gorodzha, S.N.; Muslimov, A.R.; Syromotina, D.S.; Timin, A.S.; Tcvetkov, N.Y.; Lepik, K.V.; Petrova, A.V.; Surmeneva, M.A.; Gorin, D.A.; Sukhorukov, G.B.; et al. A Comparison Study between Electrospun Polycaprolactone and Piezoelectric poly(3Hydroxybutyrate-Co-3-Hydroxyvalerate) Scaffolds for Bone Tissue Engineering. Colloids Surf. B 2017, 160, 48-59. [CrossRef]

34. Nekounam, H.; Allahyari, Z.; Gholizadeh, S.; Mirzaei, E.; Shokrgozar, M.A.; Faridi-Majidi, R. Simple and Robust Fabrication and Characterization of Conductive Carbonized Nanofibers Loaded with Gold Nanoparticles for Bone Tissue Engineering Applications. Mater. Sci. Eng. C 2020, 117, 111226. [CrossRef]

35. Zhou, T.; Li, G.; Lin, S.; Tian, T.; Ma, Q.; Zhang, Q.; Shi, S.; Xue, C.; Ma, W.; Cai, X.; et al. Electrospun Poly(3-HydroxybutyrateCo-4-Hydroxybutyrate)/Graphene Oxide Scaffold: Enhanced Properties and Promoted In Vivo Bone Repair in Rats. ACS Appl. Mater. Interfaces 2017, 9, 42589-42600. [CrossRef] [PubMed]

36. Niu, X.; Qin, M.; Xu, M.; Zhao, L.; Wei, Y.; Hu, Y.; Lian, X.; Chen, S.; Chen, W.; Huang, D. Coated Electrospun Polyamide6/Chitosan Scaffold with Hydroxyapatite for Bone Tissue Engineering. Biomed. Mater. 2021, 16, 025014. [CrossRef] [PubMed] 
37. Lopresti, F.; Pavia, F.C.; Ceraulo, M.; Capuana, E.; Brucato, V.; Ghersi, G.; Botta, L.; La Carrubba, V. Physical and Biological Properties of Electrospun Poly(D,L-Lactide)/Nanoclay and Poly(D,L-Lactide)/Nanosilica Nanofibrous Scaffold for Bone Tissue Engineering. J. Biomed. Mater. Res. Part A 2021, 109, 1-17. [CrossRef] [PubMed]

38. Abudhahir, M.; Saleem, A.; Paramita, P.; Kumar, S.D.; Tze-Wen, C.; Selvamurugan, N.; Moorthi, A. Polycaprolactone Fibrous Electrospun Scaffolds Reinforced with Copper Doped Wollastonite for Bone Tissue Engineering Applications. J. Biomed. Mater. Res. Part B 2021, 109, 654-664. [CrossRef] [PubMed]

39. Zhao, H.; Tang, J.; Zhou, D.; Weng, Y.; Qin, W.; Liu, C.; Lv, S.; Wang, W.; Zhao, X. Electrospun Icariin-Loaded Core-Shell Collagen, Polycaprolactone, Hydroxyapatite Composite Scaffolds for the Repair of Rabbit Tibia Bone Defects. Int. J. Nanomed. 2020, 15, 3039-3056. [CrossRef] [PubMed]

40. Orr, S.B.; Chainani, A.; Hippensteel, K.J.; Kishan, A.; Gilchrist, C.; Garrigues, N.W.; Ruch, D.S.; Guilak, F.; Little, D. Aligned Multilayered Electrospun Scaffolds for Rotator Cuff Tendon Tissue Engineering. Acta Biomater. 2015, 24, 117-126. [CrossRef]

41. Jordahl, J.H.; Solorio, L.; Sun, H.; Ramcharan, S.; Teeple, C.B.; Haley, H.R.; Lee, K.J.; Eyster, T.W.; Luker, G.D.; Krebsbach, P.H.; et al. 3D Jet Writing: Functional Microtissues Based on Tessellated Scaffold Architectures. Adv. Mater. 2018, 30, 1707196. [CrossRef]

42. Xie, J.; Shen, H.; Yuan, G.; Lin, K.; Su, J. The Effects of Alignment and Diameter of Electrospun Fibers on the Cellular Behaviors and Osteogenesis of BMSCs. Mater. Sci. Eng. C 2021, 120, 111787. [CrossRef]

43. Sun, B.; Long, Y.-Z.; Liu, S.-L.; Huang, Y.-Y.; Ma, J.; Zhang, H.-D.; Shen, G.; Xu, S. Fabrication of Curled Conducting Polymer Microfibrous Arrays via a Novel Electrospinning Method for Stretchable Strain Sensors. Nanoscale 2013, 5, 7041-7045. [CrossRef] [PubMed]

44. Luo, J.; Zhu, J.; Wang, L.; Kang, J.; Wang, X.; Xiong, J. Co-Electrospun Nano-/Microfibrous Composite Scaffolds with Structural and Chemical Gradients for Bone Tissue Engineering. Mater. Sci. Eng. C 2021, 119, 111622. [CrossRef] [PubMed]

45. Wang, Q.; Feng, Y.; He, M.; Zhao, W.; Qiu, L.; Zhao, C. A Hierarchical Janus Nanofibrous Membrane Combining Direct Osteogenesis and Osteoimmunomodulatory Functions for Advanced Bone Regeneration. Adv. Funct. Mater. 2020, $31,2008906$. [CrossRef]

46. Wang, C.; Wang, M. Electrospun Multicomponent and Multifunctional Nanofibrous Bone Tissue Engineering Scaffolds. J. Mater. Chem. B 2017, 5, 1388-1399. [CrossRef]

47. Ko, E.; Lee, J.S.; Kim, H.; Yang, S.Y.; Yang, D.; Yang, K.; Lee, J.; Shin, J.; Yang, H.S.; Ryu, W.; et al. Electrospun Silk Fibroin Nanofibrous Scaffolds with Two-Stage Hydroxyapatite Functionalization for Enhancing the Osteogenic Differentiation of Human Adipose-Derived Mesenchymal Stem Cells. ACS Appl. Mater. Interfaces 2018, 10, 7614-7625. [CrossRef]

48. Wu, S.; Wang, J.; Zou, L.; Jin, L.; Wang, Z.; Li, Y. A Three-Dimensional Hydroxyapatite/Polyacrylonitrile Composite Scaffold Designed for Bone Tissue Engineering. RSC Adv. 2018, 8, 1730-1736. [CrossRef]

49. Ryu, J.H.; Kwon, J.S.; Kim, K.M.; Hong, H.J.; Koh, W.G.; Lee, J.; Lee, H.J.; Choi, H.J.; Yi, S.; Shin, H.; et al. Synergistic Effect of Porous Hydroxyapatite Scaffolds Combined with Bioactive Glass/Poly(Lactic-Co-Glycolic Acid) Composite Fibers Promotes Osteogenic Activity and Bioactivity. ACS Omega 2019, 4, 2302-2310. [CrossRef]

50. Li, R.; McCarthy, A.; Zhang, Y.S.; Xie, J. Decorating 3D Printed Scaffolds with Electrospun Nanofiber Segments for Tissue Engineering. Adv. Biosyst. 2019, 3, 1900137. [CrossRef]

51. Hejazi, F.; Bagheri-Khoulenjani, S.; Olov, N.; Zeini, D.; Solouk, A.; Mirzadeh, H. Fabrication of Nanocomposite/Nanofibrous Functionally Graded Biomimetic Scaffolds for Osteochondral Tissue Regeneration. J. Biomed. Mater. Res. Part A 2021, 109, 1657-1669. [CrossRef] [PubMed]

52. Song, J.; Zhu, G.; Wang, L.; An, G.; Shi, X.; Wang, Y. Assembling of Electrospun Meshes into Three-Dimensional Porous Scaffolds for Bone Repair. Biofabrication 2017, 9, 015018. [CrossRef] [PubMed]

53. Marins, N.H.; Lee, B.E.J.; RM, E.S.; Raghavan, A.; Villarreal Carreno, N.L.; Grandfield, K. Niobium Pentoxide and Hydroxyapatite Particle Loaded Electrospun Polycaprolactone/Gelatin Membranes for Bone Tissue Engineering. Colloids Surf. B 2019, $182,110386$. [CrossRef] [PubMed]

54. Xu, J.; Fang, Q.; Liu, Y.; Zhou, Y.; Ye, Z.; Tan, W.S. In Situ Ornamenting Poly(Epsilon-Caprolactone) Electrospun Fibers with Different Fiber Diameters Using Chondrocyte-Derived Extracellular Matrix for Chondrogenesis of Mesenchymal Stem Cells. Colloids Surf. B 2021, 197, 111374. [CrossRef]

55. Kranthi Kiran, A.S.; Kizhakeyil, A.; Ramalingam, R.; Verma, N.K.; Lakshminarayanan, R.; Kumar, T.S.S.; Doble, M.; Ramakrishna, S. Drug Loaded Electrospun Polymer/Ceramic Composite Nanofibrous Coatings on Titanium for Implant Related Infections. Ceram. Int. 2019, 45, 18710-18720. [CrossRef]

56. Xu, T.; Yao, Q.; Miszuk, J.M.; Sanyour, H.J.; Hong, Z.; Sun, H.; Fong, H. Tailoring Weight Ratio of PCL/PLA in Electrospun Three-Dimensional Nanofibrous Scaffolds and the Effect on Osteogenic Differentiation of Stem Cells. Colloids Surf. B 2018, 171, 31-39. [CrossRef]

57. Wang, Y.; Cui, W.; Chou, J.; Wen, S.; Sun, Y.; Zhang, H. Electrospun Nanosilicates-Based Organic/Inorganic Nanofibers for Potential Bone Tissue Engineering. Colloids Surf. B 2018, 172, 90-97. [CrossRef]

58. Li, W.; Xu, H.; Han, X.; Sun, S.; Chai, Q.; Xu, X.; Man, Z. Simultaneously Promoting Adhesion and Osteogenic Differentiation of Bone Marrow-Derived Mesenchymal Cells by a Functional Electrospun Scaffold. Colloids Surf. B 2020, 192, 111040. [CrossRef]

59. Heydari, Z.; Mohebbi-Kalhori, D.; Afarani, M.S. Engineered Electrospun Polycaprolactone (PCL)/Octacalcium Phosphate (OCP) Scaffold for Bone Tissue Engineering. Mater. Sci. Eng. C 2017, 81, 127-132. [CrossRef] 
60. Marrella, A.; Tedeschi, G.; Giannoni, P.; Lagazzo, A.; Sbrana, F.; Barberis, F.; Quarto, R.; Puglisi, F.; Scaglione, S. “Green-Reduced” Graphene Oxide Induces In Vitro an Enhanced Biomimetic Mineralization of Polycaprolactone Electrospun Meshes. Mater. Sci. Eng. C 2018, 93, 1044-1053. [CrossRef]

61. Junka, R.; Yu, X. Polymeric Nanofibrous Scaffolds Laden with Cell-Derived Extracellular Matrix for Bone Regeneration. Mater. Sci. Eng. C 2020, 113, 110981. [CrossRef] [PubMed]

62. Awasthi, G.P.; Kaliannagounder, V.K.; Maharjan, B.; Lee, J.Y.; Park, C.H.; Kim, C.S. Albumin-Induced Exfoliation of Molybdenum Disulfide Nanosheets Incorporated Polycaprolactone/Zein Composite Nanofibers for Bone Tissue Regeneration. Mater. Sci. Eng. C 2020, 116, 111162. [CrossRef] [PubMed]

63. Deng, Y.; Yang, Y.; Wei, S. Peptide-Decorated Nanofibrous Niche Augments In Vitro Directed Osteogenic Conversion of Human Pluripotent Stem Cells. Biomacromolecules 2017, 18, 587-598. [CrossRef]

64. Porrelli, D.; Mardirossian, M.; Musciacchio, L.; Pacor, M.; Berton, F.; Crosera, M.; Turco, G. Antibacterial Electrospun Polycaprolactone Membranes Coated with Polysaccharides and Silver Nanoparticles for Guided Bone and Tissue Regeneration. ACS Appl. Mater. Interfaces 2021, 13, 17255-17267. [CrossRef] [PubMed]

65. Jirkovec, R.; Holec, P.; Hauzerova, S.; Samkova, A.; Kalous, T.; Chvojka, J. Preparation of a Composite Scaffold from Polycaprolactone and Hydroxyapatite Particles by Means of Alternating Current Electrospinning. ACS Omega 2021, 6, 9234-9242. [CrossRef]

66. Hwang, T.I.; Kim, J.I.; Lee, J.; Moon, J.Y.; Lee, J.C.; Joshi, M.K.; Park, C.H.; Kim, C.S. In Situ Biological Transmutation of Catalytic Lactic Acid Waste into Calcium Lactate in a Readily Processable Three-Dimensional Fibrillar Structure for Bone Tissue Engineering. ACS Appl. Mater. Interfaces 2020, 12, 18197-18210. [CrossRef]

67. Huang, C.; Yang, G.; Zhou, S.; Luo, E.; Pan, J.; Bao, C.; Liu, X. Controlled Delivery of Growth Factor by Hierarchical Nanostructured Core-Shell Nanofibers for the Efficient Repair of Critical-Sized Rat Calvarial Defect. ACS Biomater. Sci. Eng. 2020, 6, 5758-5770. [CrossRef]

68. Munir, N.; McDonald, A.; Callanan, A. Integrational Technologies for the Development of Three-Dimensional Scaffolds as Platforms in Cartilage Tissue Engineering. ACS Omega 2020, 5, 12623-12636. [CrossRef]

69. Metwally, S.; Karbowniczek, J.E.; Szewczyk, P.K.; Marzec, M.M.; Gruszczyński, A.; Bernasik, A.; Stachewicz, U. Single-Step Approach to Tailor Surface Chemistry and Potential on Electrospun PCL Fibers for Tissue Engineering Application. Adv. Mater. Interfaces 2019, 6, 1801211. [CrossRef]

70. Sergi, R.; Cannillo, V.; Boccaccini, A.R.; Liverani, L. Incorporation of Bioactive Glasses Containing Mg, Sr, and Zn in Electrospun PCL Fibers by Using Benign Solvents. Appl. Sci. 2020, 10, 5530. [CrossRef]

71. Wang, Y.; Cui, W.; Zhao, X.; Wen, S.; Sun, Y.; Han, J.; Zhang, H. Bone Remodeling-Inspired Dual Delivery Electrospun Nanofibers for Promoting Bone Regeneration. Nanoscale 2018, 11, 60-71. [CrossRef]

72. Zhu, Q.; Ma, Z.; Li, H.; Wang, H.; He, Y. Enhancement of Rotator Cuff Tendon-Bone Healing Using Combined Aligned Electrospun Fibrous Membranes and Kartogenin. RSC Adv. 2019, 9, 15582-15592. [CrossRef]

73. Choi, E.; Bae, S.; Kim, D.; Yang, G.H.; Lee, K.; You, H.-J.; Kang, H.J.; Gwak, S.-J.; An, S.; Jeon, H. Characterization and Intracellular Mechanism of Electrospun Poly ( $\varepsilon$-Caprolactone) (PCL) Fibers Incorporated with Bone-dECM Powder as a Potential Membrane for Guided Bone Regeneration. J. Ind. Eng. Chem. 2021, 94, 282-291. [CrossRef]

74. Yavuz, E.; Erdem, R.; Küçüksayan, E.; Akarsu, E.; Akarsu, M. Preparation and Characterization of Polyethylene Glycol Functional Hydroxyapatite/Polycaprolactone Electrospun Biomembranes for Bone Tissue Engineering Applications. Fibers Polym. 2021, 22, 1274-1284. [CrossRef]

75. Naudot, M.; Garcia Garcia, A.; Jankovsky, N.; Barre, A.; Zabijak, L.; Azdad, S.Z.; Collet, L.; Bedoui, F.; Hebraud, A.; Schlatter, G.; et al. The Combination of a Poly-Caprolactone/Nano-Hydroxyapatite Honeycomb Scaffold and Mesenchymal Stem Cells Promotes Bone Regeneration in Rat Calvarial Defects. J. Tissue Eng. Regen. Med. 2020, 14, 1570-1580. [CrossRef]

76. Sharifi, F.; Atyabi, S.M.; Norouzian, D.; Zandi, M.; Irani, S.; Bakhshi, H. Polycaprolactone/Carboxymethyl Chitosan Nanofibrous Scaffolds for Bone Tissue Engineering Application. Int. J. Biol. Macromol. 2018, 115, 243-248. [CrossRef]

77. Jinga, S.I.; Costea, C.C.; Zamfirescu, A.I.; Banciu, A.; Banciu, D.D.; Busuioc, C. Composite Fiber Networks Based on Polycaprolactone and Bioactive Glass-Ceramics for Tissue Engineering Applications. Polymers 2020, 12, 1806. [CrossRef]

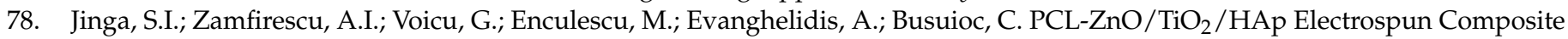
Fibers with Applications in Tissue Engineering. Polymers 2019, 11, 1793. [CrossRef] [PubMed]

79. Luginina, M.; Schuhladen, K.; Orru, R.; Cao, G.; Boccaccini, A.R.; Liverani, L. Electrospun PCL/PGS Composite Fibers Incorporating Bioactive Glass Particles for Soft Tissue Engineering Applications. Nanomaterials 2020, 10, 978. [CrossRef] [PubMed]

80. Ye, K.; Liu, D.; Kuang, H.; Cai, J.; Chen, W.; Sun, B.; Xia, L.; Fang, B.; Morsi, Y.; Mo, X. Three-Dimensional Electrospun Nanofibrous Scaffolds Displaying Bone Morphogenetic Protein-2-Derived Peptides for the Promotion of Osteogenic Differentiation of Stem Cells and Bone Regeneration. J. Colloid Interface Sci. 2019, 534, 625-636. [CrossRef] [PubMed]

81. Mohammadi, M.; Alibolandi, M.; Abnous, K.; Salmasi, Z.; Jaafari, M.R.; Ramezani, M. Fabrication of Hybrid Scaffold Based on Hydroxyapatite-Biodegradable Nanofibers Incorporated with Liposomal Formulation of BMP-2 Peptide for Bone Tissue Engineering. Nanomedicine 2018, 14, 1987-1997. [CrossRef]

82. Chen, J.; Zhang, T.; Hua, W.; Li, P.; Wang, X. 3D Porous Poly(Lactic Acid)/Regenerated Cellulose Composite Scaffolds Based on Electrospun Nanofibers for Biomineralization. Colloids Surf. A 2020, 585, 124048. [CrossRef] 
83. Li, X.; Cheng, R.; Sun, Z.; Su, W.; Pan, G.; Zhao, S.; Zhao, J.; Cui, W. Flexible Bipolar Nanofibrous Membranes for Improving Gradient Microstructure in Tendon-to-Bone Healing. Acta. Biomater. 2017, 61, 204-216. [CrossRef] [PubMed]

84. Xu, Z.; Liu, P.; Li, H.; Zhang, M.; Wu, Q. In Vitro Study on Electrospun Lecithin-Based Poly (L-Lactic Acid) Scaffolds and Their Biocompatibility. J. Biomater. Sci. Polym. Ed. 2020, 31, 2285-2298. [CrossRef] [PubMed]

85. Wang, X.; Yan, H.; Shen, Y.; Tang, H.; Yi, B.; Qin, C.; Zhang, Y. Shape Memory and Osteogenesis Capabilities of the Electrospun Poly(3-Hydroxybutyrate-Co-3-Hydroxyvalerate) Modified Poly(L-Lactide) Fibrous Mats. Tissue Eng. Part A 2021, $27,142-152$. [CrossRef] [PubMed]

86. Xu, T.; Yang, H.; Yang, D.; Yu, Z.Z. Polylactic Acid Nanofiber Scaffold Decorated with Chitosan Islandlike Topography for Bone Tissue Engineering. ACS Appl. Mater. Interfaces 2017, 9, 21094-21104. [CrossRef] [PubMed]

87. Radwan-Praglowska, J.; Janus, L.; Piatkowski, M.; Bogdal, D.; Matysek, D. 3D Hierarchical, Nanostructured Chitosan/PLA/HA Scaffolds Doped with $\mathrm{TiO}_{2} / \mathrm{Au} / \mathrm{Pt}$ NPs with Tunable Properties for Guided Bone Tissue Engineering. Polymers 2020, $12,792$. [CrossRef]

88. Wang, S.F.; Wu, Y.C.; Cheng, Y.C.; Hu, W.W. The Development of Polylactic Acid/Multi-Wall Carbon Nanotubes/Polyethylene Glycol Scaffolds for Bone Tissue Regeneration Application. Polymers 2021, 13, 1740. [CrossRef]

89. Yusof, M.R.; Shamsudin, R.; Zakaria, S.; Azmi Abdul Hamid, M.; Yalcinkaya, F.; Abdullah, Y.; Yacob, N. Electron-Beam Irradiation of the PLLA/CMS/beta-TCP Composite Nanofibers Obtained by Electrospinning. Polymers 2020, 12, 1593. [CrossRef]

90. Abazari, M.F.; Zare Karizi, S.; Hajati-Birgani, N.; Kohandani, M.; Torabinejad, S.; Nejati, F.; Nasiri, N.; Maleki, M.H.; Mohajerani, H.; Mansouri, V. Curcumin-Loaded PHB/PLLA Nanofibrous Scaffold Supports Osteogenesis in Adipose-Derived Stem Cells In Vitro. Polym. Adv. Technol. 2021, 32, 1-9. [CrossRef]

91. Patel, D.K.; Dutta, S.D.; Hexiu, J.; Ganguly, K.; Lim, K.T. Bioactive Electrospun Nanocomposite Scaffolds of Poly(Lactic Acid)/Cellulose Nanocrystals for Bone Tissue Engineering. Int. J. Biol. Macromol. 2020, 162, 1429-1441. [CrossRef]

92. Lee, S.; Joshi, M.K.; Tiwari, A.P.; Maharjan, B.; Kim, K.S.; Yun, Y.H.; Park, C.H.; Kim, C.S. Lactic Acid Assisted Fabrication of Bioactive Three-Dimensional PLLA/ $\beta$-TCP Fibrous Scaffold for Biomedical Application. Chem. Eng. J. 2018, 347, 771-781. [CrossRef]

93. Doosti-Telgerd, M.; Mahdavi, F.S.; Moradikhah, F.; Porgham Daryasari, M.; Bayrami Atashgah, R.; Dolatyar, B.; Akbari Javar, H.; Seyedjafari, E.; Shabani, I.; Arefian, E.; et al. Nanofibrous Scaffolds Containing Hydroxyapatite and Microfluidic-Prepared Polyamidoamin/BMP-2 Plasmid Dendriplexes for Bone Tissue Engineering Applications. Int. J. Nanomed. 2020, 15, $2633-2646$. [CrossRef]

94. Xie, X.; Wang, W.; Cheng, J.; Liang, H.; Lin, Z.; Zhang, T.; Lu, Y.; Li, Q. Bilayer Pifithrin-Alpha Loaded Extracellular Matrix/PLGA Scaffolds for Enhanced Vascularized Bone Formation. Colloids Surf. B 2020, 190, 110903. [CrossRef]

95. Fu, C.; Bai, H.; Hu, Q.; Gao, T.; Bai, Y. Enhanced Proliferation and Osteogenic Differentiation of Mc3t3-E1 Pre-Osteoblasts on Graphene Oxide-Impregnated PLGA-Gelatin Nanocomposite Fibrous Membranes. RSC Adv. 2017, 7, 8886-8897. [CrossRef]

96. Chen, W.; Xu, Y.; Li, Y.; Jia, L.; Mo, X.; Jiang, G.; Zhou, G. 3D Printing Electrospinning Fiber-Reinforced Decellularized Extracellular Matrix for Cartilage Regeneration. Chem. Eng. J. 2020, 382, 122986. [CrossRef]

97. Yang, X.; Li, Y.; He, W.; Huang, Q.; Zhang, R.; Feng, Q. Hydroxyapatite/Collagen Coating on PLGA Electrospun Fibers for Osteogenic Differentiation of Bone Marrow Mesenchymal Stem Cells. J. Biomed. Mater. Res. Part A 2018, 106, $2863-2870$. [CrossRef] [PubMed]

98. Januariyasa, I.K.; Ana, I.D.; Yusuf, Y. Nanofibrous Poly(Vinyl Alcohol)/Chitosan Contained Carbonated Hydroxyapatite Nanoparticles Scaffold for Bone Tissue Engineering. Mater. Sci. Eng. C 2020, 107, 110347. [CrossRef] [PubMed]

99. Bellani, C.; Yue, K.; Flaig, F.; Hebraud, A.; Ray, P.; Annabi, N.; Selistre de Araujo, H.S.; Branciforti, M.C.; Minarelli Gaspar, A.M.; Shin, S.R.; et al. Suturable Elastomeric Tubular Grafts with Patterned Porosity for Rapid Vascularization of 3D Constructs. Biofabrication 2021, 13, 035020. [CrossRef] [PubMed]

100. Enayati, M.S.; Behzad, T.; Sajkiewicz, P.; Rafienia, M.; Bagheri, R.; Ghasemi-Mobarakeh, L.; Kolbuk, D.; Pahlevanneshan, Z.; Bonakdar, S.H. Development of Electrospun Poly(Vinyl Alcohol)-Based Bionanocomposite Scaffolds for Bone Tissue Engineering. J. Biomed. Mater. Res. Part A 2018, 106, 1111-1120. [CrossRef]

101. Qi, J.; Zhang, H.; Wang, Y.; Mani, M.P.; Jaganathan, S.K. Development and Blood Compatibility Assessment of Electrospun Polyvinyl Alcohol Blended with Metallocene Polyethylene and Plectranthus amboinicus (PVA/mPE/PA) for Bone Tissue Engineering. Int. J. Nanomed. 2018, 13, 2777-2788. [CrossRef]

102. Damaraju, S.M.; Shen, Y.; Elele, E.; Khusid, B.; Eshghinejad, A.; Li, J.; Jaffe, M.; Arinzeh, T.L. Three-Dimensional Piezoelectric Fibrous Scaffolds Selectively Promote Mesenchymal Stem Cell Differentiation. Biomaterials 2017, 149, 51-62. [CrossRef]

103. Rodrigues, P.J.G.; Elias, C.d.M.V.; Viana, B.C.; de Hollanda, L.M.; Stocco, T.D.; de Vasconcellos, L.M.R.; Mello, D.d.C.R.; Santos, F.E.P.; Marciano, F.R.; Lobo, A.O. Electrodeposition of Bactericidal and Bioactive Nano-Hydroxyapatite onto Electrospun Piezoelectric Polyvinylidene Fluoride Scaffolds. J. Mater. Res. 2020, 35, 3265-3275. [CrossRef]

104. Massoumi, B.; Abbasian, M.; Jahanban-Esfahlan, R.; Mohammad-Rezaei, R.; Khalilzadeh, B.; Samadian, H.; Rezaei, A.; Derakhshankhah, H.; Jaymand, M. A Novel Bio-Inspired Conductive, Biocompatible, and Adhesive Terpolymer Based on Polyaniline, Polydopamine, and Polylactide as Scaffolding Biomaterial for Tissue Engineering Application. Int. J. Biol. Macromol. 2020, 147, 1174-1184. [CrossRef] 
105. Luo, J.; Zhang, H.; Zhu, J.; Cui, X.; Gao, J.; Wang, X.; Xiong, J. 3-D Mineralized Silk Fibroin/Polycaprolactone Composite Scaffold Modified with Polyglutamate Conjugated with BMP-2 Peptide for Bone Tissue Engineering. Colloids Surf. B 2018, 163, 369-378. [CrossRef]

106. Ding, H.; Zhong, J.; Xu, F.; Song, F.; Yin, M.; Wu, Y.; Hu, Q.; Wang, J. Establishment of 3D Culture and Induction of Osteogenic Differentiation of Pre-Osteoblasts Using Wet-Collected Aligned Scaffolds. Mater. Sci. Eng. C 2017, 71, 222-230. [CrossRef]

107. Gao, Y.; Shao, W.; Qian, W.; He, J.; Zhou, Y.; Qi, K.; Wang, L.; Cui, S.; Wang, R. Biomineralized Poly(L-Lactic-Co-glycolic Acid)-Tussah Silk Fibroin Nanofiber Fabric with Hierarchical Architecture as a Scaffold for Bone Tissue Engineering. Mater. Sci. Eng. C 2018, 84, 195-207. [CrossRef] [PubMed]

108. Ren, K.; Wang, Y.; Sun, T.; Yue, W.; Zhang, H. Electrospun PCL/Gelatin Composite Nanofiber Structures for Effective Guided Bone Regeneration Membranes. Mater. Sci. Eng. C 2017, 78, 324-332. [CrossRef] [PubMed]

109. Gautam, S.; Sharma, C.; Purohit, S.D.; Singh, H.; Dinda, A.K.; Potdar, P.D.; Chou, C.F.; Mishra, N.C. Gelatin-PolycaprolactoneNanohydroxyapatite Electrospun Nanocomposite Scaffold for Bone Tissue Engineering. Mater. Sci. Eng. C 2021, $119,111588$. [CrossRef] [PubMed]

110. Yu, F.; Li, M.; Yuan, Z.; Rao, F.; Fang, X.; Jiang, B.; Wen, Y.; Zhang, P. Mechanism Research on a Bioactive Resveratrol-PLA-Gelatin Porous Nano-Scaffold in Promoting the Repair of Cartilage Defect. Int. J. Nanomed. 2018, 13, 7845-7858. [CrossRef] [PubMed]

111. Zhou, G.; Liu, S.; Ma, Y.; Xu, W.; Meng, W.; Lin, X.; Wang, W.; Wang, S.; Zhang, J. Innovative Biodegradable Poly(LLactide)/Collagen/Hydroxyapatite Composite Fibrous Scaffolds Promote Osteoblastic Proliferation and Differentiation. Int. J. Nanomed. 2017, 12, 7577-7588. [CrossRef]

112. Bassat, E.; Mutlak, Y.E.; Genzelinakh, A.; Shadrin, I.Y.; Baruch Umansky, K.; Yifa, O.; Kain, D.; Rajchman, D.; Leach, J.; Riabov Bassat, D.; et al. The Extracellular Matrix Protein Agrin Promotes Heart Regeneration in Mice. Nature 2017, 547, 179-184. [CrossRef]

113. Flaumenhaft, R.; Rifkin, D.B. Extracellular Matrix Regulation of Growth Factor and Protease Activity. Curr. Opin. Cell Biol. 1991, 3, 817-823. [CrossRef]

114. Walker, A.; Turnbull, J.E.; Gallagher, J.T. Specific Heparan Sulfate Saccharides Mediate the Activity of Basic Fibroblast Growth Factor. J. Biol. Chem. 1994, 269, 931-935. [CrossRef]

115. Liu, G.; Gu, Z.; Hong, Y.; Cheng, L.; Li, C. Electrospun Starch Nanofibers: Recent Advances, Challenges, and Strategies for Potential Pharmaceutical Applications. J. Control. Release 2017, 252, 95-107. [CrossRef]

116. Liao, Y.; Loh, C.H.; Tian, M.; Wang, R.; Fane, A.G. Progress in Electrospun Polymeric Nanofibrous Membranes for Water Treatment: Fabrication, Modification and Applications. Prog. Polym. Sci. 2018, 77, 69-94. [CrossRef]

117. Fukada, E.; Yasuda, I. On the Piezoelectric Effect of Bone. J. Phys. Soc. Jpn. 1957, 12, 1158-1162. [CrossRef]

118. Yasuda, I. Electrical Callus and Callus Formation by Electret. Clin. Orthop. Relat. Res. 1977, 124, 53-56. [CrossRef]

119. Kitsara, M.; Blanquer, A.; Murillo, G.; Humblot, V.; De Braganca Vieira, S.; Nogues, C.; Ibanez, E.; Esteve, J.; Barrios, L. Permanently Hydrophilic, Piezoelectric PVDF Nanofibrous Scaffolds Promoting Unaided Electromechanical Stimulation on Osteoblasts. Nanoscale 2019, 11, 8906-8917. [CrossRef] [PubMed]

120. Murillo, G.; Blanquer, A.; Vargas-Estevez, C.; Barrios, L.; Ibáñez, E.; Nogués, C.; Esteve, J. Electromechanical Nanogenerator-Cell Interaction Modulates Cell Activity. Adv. Mater. 2017, 29, 1-7. [CrossRef]

121. Wolfenson, H.; Lavelin, I.; Geiger, B. Dynamic Regulation of the Structure and Functions of Integrin Adhesions. Dev. Cell 2013, 24, 447-458. [CrossRef] [PubMed]

122. Su, Z.; Li, J.; Ouyang, Z.; Arras, M.M.L.; Wei, G.; Jandt, K.D. Biomimetic 3D Hydroxyapatite Architectures with Interconnected Pores Based on Electrospun Biaxially Orientated PCL Nano-Fibers. RSC Adv. 2014, 4, 14833-14839. [CrossRef]

123. Zhang, M.; Zhao, X.; Zhang, G.; Wei, G.; Su, Z. Electrospinning Design of Functional Nanostructures for Biosensor Applications. J. Mater. Chem. B 2017, 5, 1699-1711. [CrossRef] [PubMed]

124. Arras, M.M.L.; Jana, R.; Mühlstädt, M.; Maenz, S.; Andrews, J.; Su, Z.; Grasl, C.; Jandt, K.D. In Situ Formation of Nanohybrid Shish-Kebabs during Electrospinning for the Creation of Hierarchical Shish-Kebab Structures. Macromolecules 2016, 49, 3550-3558. [CrossRef]

125. Yu, X.; Park, H.S. Synthesis and Characterization of Electrospun PAN/2D MoS 2 Composite Nanofibers. J. Ind. Eng. Chem. 2016, 34, 61-65. [CrossRef]

126. Wu, S.; Wang, J.; Jin, L.; Li, Y.; Wang, Z. Effects of Polyacrylonitrile/MoS 2 Composite Nanofibers on the Growth Behavior of Bone Marrow Mesenchymal Stem Cells. ACS Appl. Nano Mater. 2017, 1, 337-343. [CrossRef]

127. Jing, X.; Mi, H.Y.; Wang, X.C.; Peng, X.F.; Turng, L.S. Shish-Kebab-Structured Poly( $\varepsilon$-Caprolactone) Nanofibers Hierarchically Decorated with Chitosan-Poly(E-Caprolactone) Copolymers for Bone Tissue Engineering. ACS Appl. Mater. Interfaces 2015, 7 , 6955-6965. [CrossRef]

128. Xu, Y.; Peng, J.; Dong, X.; Xu, Y.; Li, H.; Chang, J. Combined Chemical and Structural Signals of Biomaterials Synergistically Activate Cell-Cell Communications for Improving Tissue Regeneration. Acta. Biomater. 2017, 55, 249-261. [CrossRef]

129. Jing, X.; Mi, H.Y.; Peng, J.; Peng, X.F.; Turng, L.S. Electrospun Aligned Poly(Propylene Carbonate) Microfibers with Chitosan Nanofibers as Tissue Engineering Scaffolds. Carbohydr. Polym. 2015, 117, 941-949. [CrossRef]

130. Pelipenko, J.; Kocbek, P.; Kristl, J. Nanofiber Diameter as a Critical Parameter Affecting Skin Cell Response. Eur. J. Pharm. Sci. 2015, 66, 29-35. [CrossRef] 
131. Wright, L.D.; Young, R.T.; Andric, T.; Freeman, J.W. Fabrication and Mechanical Characterization of 3D Electrospun Scaffolds for Tissue Engineering. Biomed. Mater. 2010, 5, 055006. [CrossRef] [PubMed]

132. Hoang, Q.Q.; Sicheri, F.; Howard, A.J.; Yang, D.S.C. Bone Recognition Mechanism of Porcine Osteocalcin from Crystal Structure. Nature 2003, 425, 977-980. [CrossRef] [PubMed]

133. Culpepper, B.K.; Webb, W.M.; Bonvallet, P.P.; Bellis, S.L. Tunable Delivery of Bioactive Peptides from Hydroxyapatite Biomaterials and Allograft Bone Using Variable-Length Polygluta-Mate Domains. J. Biomed. Mater. Res. Part A 2014, 102, 1008-1016. [CrossRef] [PubMed]

134. Zia, Q.; Tabassum, M.; Lu, Z.; Khawar, M.T.; Song, J.; Gong, H.; Meng, J.; Li, Z.; Li, J. Porous Poly(L-Lactic Acid)/Chitosan Nanofibres for Copper Ion Adsorption. Carbohydr. Polym. 2020, 227, 115343. [CrossRef] [PubMed]

135. Song, J.; Zhang, B.; Lu, Z.; Xin, Z.; Liu, T.; Wei, W.; Zia, Q.; Pan, K.; Gong, R.H.; Bian, L.; et al. Hierarchical Porous Poly(L-lactic acid) Nanofibrous Membrane for Ultrafine Particulate Aerosol Filtration. ACS Appl. Mater. Interfaces 2019, 11, 46261-46268. [CrossRef]

136. Zahari, N.K.; Idrus, R.B.; Chowdhury, S.R. Laminin-Coated Poly(Methyl Methacrylate) (PMMA) Nanofiber Scaffold Facilitates the Enrichment of Skeletal Muscle Myoblast Population. Int. J. Mol. Sci. 2017, 18, 2242. [CrossRef] [PubMed]

137. Heinrich, M.A.; Liu, W.; Jimenez, A.; Yang, J.; Akpek, A.; Liu, X.; Pi, Q.; Mu, X.; Hu, N.; Schiffelers, R.M.; et al. 3D Bioprinting: From Benches to Translational Applications. Small 2019, 15, 1805510. [CrossRef] [PubMed]

138. Xu, T.; Miszuk, J.M.; Zhao, Y.; Sun, H.; Fong, H. Electrospun Polycaprolactone 3D Nanofibrous Scaffold with Interconnected and Hierarchically Structured Pores for Bone Tissue Engineering. Adv. Healthc. Mater. 2015, 4, 2238-2246. [CrossRef]

139. Hwang, T.I.; Maharjan, B.; Tiwari, A.P.; Lee, S.; Joshi, M.K.; Park, C.H.; Kim, C.S. Facile Fabrication of Spongy Nanofibrous Scaffold for Tissue Engineering Applications. Mater. Lett. 2018, 219, 119-122. [CrossRef]

140. Ranjbarzadeh-Dibazar, A.; Barzin, J.; Shokrollahi, P. Microstructure Crystalline Domains Disorder Critically Controls Formation of Nano-Porous/Long Fibrillar Morphology of ePTFE Membranes. Polymer 2017, 121, 75-87. [CrossRef]

141. Park, J.Y.; Lee, J.H.; Kim, C.H.; Kim, Y.J. Fabrication of Polytetrafluoroethylene Nanofibrous Membranes for Guided Bone Regeneration. RSC Adv. 2018, 8, 34359-34369. [CrossRef]

142. Bao, M.; Wang, X.; Yuan, H.; Lou, X.; Zhao, Q.; Zhang, Y. HAp Incorporated Ultrafine Polymeric Fibers with Shape Memory Effect for Potential Use in Bone Screw Hole Healing. J. Mater. Chem. B 2016, 4, 5308-5320. [CrossRef] [PubMed]

143. Sobota, M.; Jurczyk, S.; Kwiecień, M.; Smola-Dmochowska, A.; Musioł, M.; Domański, M.; Janeczek, H.; Kawalec, M.; Kurcok, P. Crystallinity as a Tunable Switch of Poly(L-Lactide) Shape Memory Effects. J. Mech. Behav. Biomed. Mater. 2017, 66, 144-151. [CrossRef]

144. Ghobadi, E.; Heuchel, M.; Kratz, K.; Lendlein, A. Influence of the Addition of Water to Amorphous Switching Domains on the Simulated Shape-Memory Properties of Poly(L-Lactide). Polymer 2013, 54, 4204-4211. [CrossRef]

145. Wong, Y.S.; Venkatraman, S.S. Recovery as a Measure of Oriented Crystalline Structure in poly(L-Lactide) Used as Shape Memory Polymer. Acta Mater. 2010, 58, 49-58. [CrossRef]

146. Xie, X.; Cai, J.; Yao, Y.; Chen, Y.; Khan, A.u.R.; Wu, J.; Mo, X. A Woven Scaffold with Continuous Mineral Gradients for Tendon-to-Bone Tissue Engineering. Compos. Part B 2021, 212, 108679. [CrossRef]

147. Chen, Z.; Song, Y.; Zhang, J.; Liu, W.; Cui, J.; Li, H.; Chen, F. Laminated Electrospun nHA/PHB-Composite Scaffolds Mimicking Bone Extracellular Matrix for Bone Tissue Engineering. Mater. Sci. Eng. C 2017, 72, 341-351. [CrossRef] [PubMed]

148. Butler, M.F.; Ng, Y.F.; Pudney, P.D.A. Mechanism and Kinetics of the Crosslinking Reaction between Biopolymers Containing Primary Amine Groups and Genipin. J. Polym. Sci. Part A Polym. Chem. 2003, 41, 3941-3953. [CrossRef]

149. Yang, Y.; Xu, T.; Zhang, Q.; Piao, Y.; Bei, H.P.; Zhao, X. Biomimetic, Stiff, and Adhesive Periosteum with Osteogenic-Angiogenic Coupling Effect for Bone Regeneration. Small 2021, 17, 2006598. [CrossRef] [PubMed]

150. Bose, S.; Tarafder, S. Calcium Phosphate Ceramic Systems in Growth Factor and Drug Delivery for Bone Tissue Engineering: A Review. Acta Biomater. 2012, 8, 1401-1421. [CrossRef]

151. Zimmerli, W.; Widmer, A.F.; Blatter, M.; Frei, R.; Ochsner, P.E.; Foreign-Body Infection Study Group. Role of Rifampin for Treatment of Orthopedic Implant-Related Staphylococcal Infections a Randomized Controlled Trial. JAMA 1998, 279, 1537-1541. [CrossRef] [PubMed]

152. Coiffier, G.; Albert, J.D.; Arvieux, C.; Guggenbuhl, P. Optimizing Combination Rifampin Therapy for Staphylococcal Osteoarticular Infections. Jt. Bone Spine 2013, 80, 11-17. [CrossRef] [PubMed]

153. Wang, C.; Lu, W.W.; Wang, M. Multifunctional Fibrous Scaffolds for Bone Regeneration with Enhanced Vascularization. J. Mater Chem. B 2020, 8, 636-647. [CrossRef] [PubMed]

154. Reed, S.; Wu, B. Sustained Growth Factor Delivery in Tissue Engineering Applications. Ann. Biomed. Eng. 2014, 42, 1528-1536. [CrossRef] [PubMed]

155. Vonau, R.L.; Bostrom, M.P.G.; Aspenberg, P.; Sams, A.E. Combination of Growth Factors Inhibits Bone Ingrowth in the Bone Harvest Chamber. Clin. Orthop. Relat. Res. 2001, 386, 243-251. [CrossRef]

156. Ibrahim, S.; Rezk, M.Y.; Ismail, M.; Abdelrahman, T.; Sharkawy, M.; Abdellatif, A.; Allam, N.K. Coaxial Nanofibers Outperform Uniaxial Nanofibers for the Loading and Release of Pyrroloquinoline Quinone (PQQ) for Bio-Medical Applications. Nanoscale Adv. 2020, 2, 3341-3349. [CrossRef] 